\title{
Cyanobacteria blooms in the Baltic Sea: a review of models and facts
}

\author{
Britta Munkes $^{1}$, Ulrike Löptien ${ }^{1,2}$, and Heiner Dietze ${ }^{1,2}$ \\ ${ }^{1}$ GEOMAR, Helmholtz Centre for Ocean Research Kiel, Düsternbrooker Weg 20, 24105 Kiel, Germany \\ ${ }^{2}$ Institute of Geosciences, Christian Albrechts University of Kiel, Ludewig-Meyn-Str. 10, 24118 Kiel, Germany
}

Correspondence: Britta Munkes (bmunkes@geomar.de)

Received: 30 April 2020 - Discussion started: 19 May 2020

Revised: 15 December 2020 - Accepted: 10 February 2021 - Published: 13 April 2021

\begin{abstract}
The ecosystem of the Baltic Sea is endangered by eutrophication. This has triggered expensive international management efforts. Some of these efforts are impeded by natural processes such as nitrogen-fixing cyanobacteria blooms that add bioavailable nitrogen to the already overfertilized system and thereby enhance primary production, export of organic matter to depth, and associated oxygen consumption. Controls of cyanobacteria blooms are not comprehensively understood, and this adds to the uncertainty of model-based projections into the warming future of the Baltic Sea. Here we review our current understanding of cyanobacteria bloom dynamics. We summarize published field studies and laboratory experiments and dissect the basic principles ingrained in state-of-the-art coupled oceancirculation biogeochemical models.
\end{abstract}

\section{Introduction}

The Baltic Sea is a shallow, brackish, and semi-enclosed sea in central northern Europe. Its drainage basin is densely populated by around 84 million people. Their footprint exerts pressure on the ecosystem (Unger et al., 2013; Hannerz and Destouni, 2006). One particularly severe problem is eutrophication. Anthropogenic nutrients enter the Baltic Sea via rivers and air-sea fluxes (Helcom, 2014, 2018a). Starting with the first Helsinki Convention in 1974, several international environmental management plans have been put to work, so far with varying degrees of success (e.g. Helsinki Convention, EU Marine Strategy Framework Directive, Baltic Sea Action Plan). On the one hand the Baltic Sea is one of the best investigated and managed seas in the world (Helcom, 2018b), where international efforts have been successful in reducing nutrient loads considerably (Helcom, 2018a). On the other hand, despite all the resourceintensive management efforts, the state of the ecosystem has not significantly improved yet (HOLAS II core indicator report, 2017; Gustafsson et al., 2017). One major cause is considered to be related to sedimentary processes. Another concern is nitrogen-fixing cyanobacteria blooms, which are suspected to become more prevalent with warming temperatures.

The ability of cyanobacteria to utilize dinitrogen, a virtually unlimited resource in the air, and to convert it into bioavailable nitrogen, links their dynamics closely to the eutrophication problem of the Baltic Sea by adding nutrients to an already over-fertilized ecosystem. There is consensus that the fixed nitrogen is a major contribution to the overall nutrient budget. Quantitative estimates range from $20 \%$ to $50 \%$ of the total new nitrogen supply (as opposed to regenerated nitrogen) that is available to the phytoplankton community (Adam et al., 2016; Gustafsson et al., 2017; Moisander et al., 2007; Vahtera et al., 2005; Whitton and Potts, 2002; Ploug et al., 2011). The future evolution of the total new nitrogen input is, however, not clear yet. While with rising temperatures increasing blooms are likely (Carey et al., 2012; Paerl, 2014), the effects of environmental management-induced changes in nutrient loads are less clear: one argument is that a reduction of the loads will have no net effect on the nutrient budget because cyanobacteria will compensate the reduction by fixing additional atmospheric nitrogen. A contrary view suggests that reduced loads will decrease primary productivity because nitrogen fixation is capped and cannot fully compensate reductions in nutrient loads (Molot et al., 2014). Among 
the reasons for a capped fixation are (1) limited availability of light which throttles the metabolically expensive process of fixation, (2) limited bioavailability of one or several of the following elements, phosphorus, iron, and molybdenum, and (3) turbulent water movement (Moisander et al., 2002; Paerl and Huisman, 2009).

Some of the reviewed studies on cyanobacteria assume that global warming will exacerbate the existing oxygen deficiency in the Baltic Sea. Warming decreases the solubility of oxygen in seawater, which leads to lower oxygen concentrations. Further, warming conditions may favour cyanobacteria because they are better adapted to oligotrophy and they benefit from the increased light levels that come along with increased stratification in response to increased air-sea heat fluxes (Carey et al., 2012; Paerl and Huisman, 2009; Andersson et al., 2015b). Increased nitrogen fixation helps to overcome oligotrophy and increases primary production and subsequent export of organic matter to depth. This in turn feeds remineralization and drives oxygen consumption at depth. Potentially evolving hypoxic or even anoxic environments may then prove lethal to fish and their fry (Elmgren, 2001; Elmgren and Larsson, 2001b; Nehring and Matthäus, 1991; Gustafsson, 2012; Diaz and Rosenberg, 2008, 1995; Breitburg et al., 2018). One problem that makes consequences of this chain of events so unpredictable and a precise quantitative process understanding so desirable is the existence of a positive feedback loop where low-oxygen conditions may drive $\mathrm{P}$ release from the sediments. This excess $\mathrm{P}$ (which comes without the Redfield $\mathrm{N}$ equivalent to the system) may fuel additional cyanobacteria blooms (Conley et al., 2002; Savchuk, 2018; Stigebrandt et al., 2014; Vahtera et al., 2007b), thereby closing the positive feedback loop.

Further motivation to understand cyanobacteria dynamics in the Baltic Sea comes from some of the species' capability to release toxins. There is evidence that the production of cyanobacterial toxins can increase with increasing nitrogen supply (Gobler et al., 2016; Dolman et al., 2012). Furthermore, it has been found in cultures that toxicity peaks when growth of the respective cyanobacteria is optimal (Lehtimäki et al., 1997). This is problematic because the toxins can lead to mass die-offs of mammals, fish, and filtering organisms (cf. Breitburg et al., 2018; Sipiä et al., 2001; Karlsson et al., 2005; Paerl, 2014; Hense, 2007; Hense and Beckmann, 2010; Kuznetsov et al., 2008; Mazur-Marzec et al., 2013; Stal et al., 2003). In the Baltic one of the most relevant cyanobacteria species, Nodularia spumigena, produces the toxin Nodularin. An additional thread comes from Dolichospermum sp. and Aphanizomenon flos-aquae, which are also able to produce toxins. In addition to toxicity, intense cyanobacteria blooms can lead to a detrimental loss of water clarity. In shallow coastal areas this can shade benthic macrophytes, thereby effectively reducing their growth and survival, which in turn has negative effects on invertebrates and fish that use macrophytes as a habitat for food and shelter (Short and WyllieEcheverria, 1996).
Despite the importance of cyanobacteria for the Baltic Sea ecosystem, the processes involved in the bloom formation of cyanobacteria are still not comprehensively understood (Hense and Beckmann, 2006; Shimoda and Arhonditsis, 2015; Taranu et al., 2012). Numerous abiotic and biotic factors promoting cyanobacteria growth have been suggested and are often controversially discussed (e.g. Unger et al., 2013). Our present understanding of the dynamics of cyanobacteria, as summarized in biogeochemical ocean models, relies mainly on empirical field correlations rather than on a comprehensive understanding of physiological responses to environmental conditions. These correlations, however, may well break under changing environmental conditions, thereby retarding model-based forecasts of the effects of potentially expensive management efforts.

In summary, deficient process understanding introduces considerable uncertainty to projections of numerical biogeochemical models, both globally (e.g. Landolfi et al., 2018) and in the Baltic Sea (e.g. Meier et al., 2012, their Fig. 7). Even so, such projections often support environmental management decisions. This study summarizes knowledge about cyanobacteria dynamics in the Baltic Sea and compares it with current state-of-the-art biogeochemical Baltic Sea models. Our aim is to identify knowledge gaps, thereby promoting the development of more reliable models. More specifically, we will (1) dissect the current generation of biogeochemical Baltic Sea models in an attempt to understand their underlying paradigms of cyanobacteria competitiveness and (2) review published studies focussed on observations and experimental results on controls of the most dominant cyanobacteria species in the Baltic: Aphanizomenon flos-aquae, Dolichospermum sp., and Nodularia spumigena (Suikkanen et al., 2010).

We start with a comparison of five state-of-the-art model approaches in Sect. 2. Section 3 puts the model assumptions in the context of published observational and experimental studies. We will end with a discussion and summary in Sects. 4 and 5, respectively.

\section{Current model approaches}

In the following we compare five coupled biogeochemical Baltic Sea models in terms of their mathematical formulations and underlying assumptions. Our choice of five is motivated by picking those that represent the state of the art conveyed to stakeholders; i.e. results from this class of models influence political decision-making (cf. Eilola et al., 2011; Meier et al., 2012, 2014; Neumann et al., 2002, 2012; Meier et al., 2011a).

Four of the biogeochemical models, dissected here, are coupled to full ocean circulation models: CEMBS (Dzierzbicka-Głowacka et al., 2013; Nowicki et al., 2015, 2016), ECOSMO II (e.g. Daewel and Schrum, 2013, 2017), ERGOM (e.g. Janssen et al., 2004; Kremp et 
al., 2007; Kuznetsov et al., 2008; Neumann et al., 2002; Neumann and Schernewski, 2005, 2008; Schernewski and Neumann, 2005), and SCOBI (e.g. Almroth-Rosell et al., 2011; Eilola et al., 2009; Meier et al., 2011b). In addition, we include BALTSEM which, although it is a box model rather than a full-fledged coupled ocean-circulation biogeochemical model, BALTSEM has impacted stakeholders considerably ever since it was developed in the early 1990s in an attempt to support the Baltic Marine Environment Protection Commission - Helsinki Commission (HELCOM) and to develop the HELCOM Baltic Sea Action Plan (Gustafsson et al., 2017; Savchuk, 2002; Savchuk et al., 2012). Specifically, we will review the reference version of BALTSEM, as initially developed for the Gulf of Riga (Savchuk, 2002).

\subsection{General model structures}

CEMBS, ECOSMO, ERGOM, SCOBI, and BALTSEM are all mechanistic models as opposed to statistical models. They are, essentially, a set of partial differential equations that describe the temporal evolution of prognostic entities of relevance or interest. Typical entities of relevance are variables such as nutrient, phytoplankton, and zooplankton concentrations. For each of these prognostic variables an equation is defined which relates their respective temporal derivative to their biogeochemical sources and sinks which, typically, are interlaced. For example, the equation for phytoplankton comprises a sink term associated with zooplankton grazing. This sink term appears as a source in the zooplankton equation and thereby interlaces the zooplankton equation with the phytoplankton equation.

Complexity in mechanistic models that are based on partial differential equations is associated with the number of explicitly resolved prognostic variables and the number of source and sink terms for each of the variables. Conceptual problems arise because there is no consensus concerning both the number of prognostic variables and the mathematical formulations of the respective source and sink terms. Typically, the respective parameters and formulations are based on abductive reasoning which introduces substantial uncertainty to the realism of the model dynamics. An additional, albeit related, uncertainty is associated with the choice of model parameters: as a rule of thumb, each source and sink term necessitates at least one parameter. Such parameters are typically not well constrained even though they determine the model behaviour in a fundamental way. Examples of these parameters are the maximum growth rate of phytoplankton and parameters which define the limiting effects of nutrientand light-depleted conditions on autotrophic growth.

All models considered here are similar in that primary production fuelled by photosynthetically available radiation generates phytoplankton biomass which is proportional to the uptake of dissolved nutrients (BALTSEM being somewhat different here because, by applying a variable Redfield ratio, it links nutrient uptake to carbon assimilation in a more flexible way than the other models investigated here). Explicitly resolved nutrients are nitrate, ammonium, phosphate (in all models considered here), and silicate in those models that explicitly resolve diatoms (BLATSEM, CEMBS, ECOSMO only). The availability of nutrients in combination with light and temperature typically determines phytoplankton growth rates.

It is common practice to group phytoplankton species into functional groups for each of which a distinct set of model parameters is defined. The models considered here are similar to one another in that they all differentiate between three functional groups with diatoms, cyanobacteria being common to all of them. As for the third group, ECOSMO, ERGOM, and SCOBI refer to it as flagellates, BALTSEM as summer species, and CEMBS as small phytoplankton.

A basic concept of the current generation of biogeochemical models is generally the widespread paradigm that diazotrophic cyanobacteria grow more slowly than ordinary phytoplankton and can, therefore, in most models only thrive when nitrogen is no longer accessible to ordinary phytoplankton (LaRoche and Breitbarth, 2005; Hense and Beckmann, 2006; Deutsch et al., 2007)

The phytoplankton bloom dynamics is generally determined by nutrient availability, which is the obvious reason for the nitrogen depletion in surface waters. Losses to phytoplankton abundances are set by sink terms which are designed to account for viral lysis, extracellular release, and zooplankton grazing. All models considered here resolve one functional group of zooplankton, with the exception of the ECOSMO model, which resolves two (micro- and macrozooplankton). As a general rule, the model parameters associated with zooplankton growth (fuelled by grazing on phytoplankton) are tuned such that phytoplankton losses exceed the growth, which ultimately leads to a termination of blooms at the right time of the year. One may argue that the representation of zooplankton is more of a closure term than an attempt to realistically simulate zooplankton dynamics. In any case this approach calls for the definition of additional closure or sink terms for zooplankton. These sink terms for zooplankton (biomass) typically comprise the production of fecal pellets and death. Fecal pellets and dead zooplankton are the source of detritus (another prognostic variable) which sinks to depths where it is remineralized or lost to the sediment.

Typical attachments to the generic model backbone mapped out above are additional prognostic variables such as oxygen and carbon (cf. CEMBS and a later version of ERGOM, Kuznetsov and Neumann, 2013) and a basic representation of the sediment. These are, however, beyond the scope of this review, which focusses on cyanobacteria.

In the following we will elucidate differences among the models which, even though they share a similar basic structure, might feature very different sensitivities to changing environmental conditions simply due to differing details in the specific formulations. 
Table 1. Coupled biogeochemical ocean models considered in this study. Note that models evolve over time. We refer to the referenced versions below.

\begin{tabular}{ll}
\hline Model & Reference \\
\hline BALTSEM & Savchuck (2002) \\
CEMBS & Dzierzbicka-Głowacka et al. (2013) \\
ECOSMO & Daewel and Schrum (2013) \\
ERGOM & Neumann et al. (2002) \\
SCOBI & Eilola et al. (2009) \\
\hline
\end{tabular}

\subsection{Growth formulation of cyanobacteria}

In this subsection, we compare the formulations of cyanobacteria growth. Special emphasis is given to the relations of cyanobacteria growth to the respective other two functional phytoplankton groups, because these relations inherently define the niche for cyanobacteria (i.e. the conditions under which they may outcompete other functional groups). Table 2 provides an overview for biogeochemical modellers in that it lists all model parameters considered in this study. In the following we will elaborate on the respective differences.

There is consensus among the models that the growth of cyanobacteria is controlled by the availability of light, temperature, and phosphate. All the models assume that high temperatures accelerate the growth. The respective functional forms and thresholds, however, differ between models, with the ERGOM model requiring the highest temperatures to permit growth (Fig. 1a). The SCOBI and ECOSMO models include an additional switch which shuts down cyanobacterial growth at salinities above 10 and 11.5 PSU, respectively. Yet another level of complexity is added in SCOBI, where growth necessitates oxygen concentrations above $0.1 \mathrm{~mL} \mathrm{O}_{2} \mathrm{~L}^{-1}$, with growth gradually increasing above this oxygen threshold.

The model behaviour is imprinted by their respective mathematical formulations and several, often rather poorly, constrained model parameters. All models considered here share the concept of a maximum growth rate that is multiplied by other expressions that represent the external factors that limit this maximum growth capability. The actual maximum growth rates applied (cf. Table 3) differ considerably among the models: in CEMBS (and ERGOM) the maximum growth of cyanobacteria is (less than) half compared to other models. CEMBS and ERGOM assume that cyanobacteria grow, even at their maximum, rather slowly compared to the other functional groups. In the other models, these differences are less pronounced. Figure 1 puts this comparison into perspective by accounting for the respective modulation by the water temperature. SCOBI and BALTSEM are strongly affected by water temperatures: cyanobacteria grow more than twice as fast at temperatures between 12 and $14{ }^{\circ} \mathrm{C}$ than at temperatures below $12^{\circ} \mathrm{C}$, and growth accelerates further with rising temperatures (Fig. 1a). Above $15^{\circ} \mathrm{C}$ cyanobacteria grow almost as fast as diatoms (cf. Fig. 1b). ERGOM does also account for the effects of ambient temperatures, but the sensitivity is lower. For one, growth never accelerates above the maximum growth rate of $0.5 \mathrm{~d}^{-1}$ (thus, in contrast to SCOBI, ERGOM's maximum growth rate is really a maximum rate). The ERGOM model stalls all cyanobacteria growth below $12^{\circ} \mathrm{C}$ and sets maximum growth at temperatures exceeding $\approx 19^{\circ} \mathrm{C}$. In contrast, the assumed increase in growth with temperature is rather gradual in the CEMBS model. The ECOSMO model includes a comparably weak temperature dependence for cyanobacteria growth (Ute Daewel, personal communication, 2020). This model does, however, include a strong light dependence of cyanobacteria growth, which presumably has a very similar effect because high light levels are typically related to high incoming solar radiation and shallow surface mixedlayer depths which, in turn, are typically related to higher surface temperatures.

The maximum growth as defined by the modulation of the maximum growth rate by the respective temperature sensitivity is damped under nutrient- and/or light-depleted conditions. The models under consideration differ considerably in this implementation. In SCOBI, the limitation of growth is implemented by multiplying by several factors, all of which are smaller than 1. Each factor describes the limiting effect of one resource (such as phosphate concentration or availability of light). The other models apply the concept of Liebig, which assumes that the limitation is set by the most depleted essential resource rather than being the result of the combined effect of various depleted resources that potentially modulate one another.

All models considered here agree that the growth of cyanobacteria depends on the availability of light and phosphate, while other macro-nutrients are not limiting. Phosphate limitation is implemented by using a "MichaelisMenten formulation" (i.e. $\frac{\mathrm{PO}_{4}^{3-}}{\mathrm{PO}_{4}^{3-}+\mathrm{K}_{\mathrm{P}}}$ ). The respective halfsaturation constant, $\mathrm{K}_{\mathrm{P}}$, varies substantially between models (Table 3), which imprints different sensitivities to phosphate limitation into their respective dynamics. Among the models, ERGOM is special in that it squares all terms (i.e. $\left.\frac{\left(\mathrm{PO}_{4}^{3-}\right)^{2}}{\left(\mathrm{PO}_{4}^{3-}\right)^{2}+\mathrm{K}_{\mathrm{P}}^{2}}\right)$, which steepens the nutrient-limitation curve considerably, effectively setting a threshold rather than a gradual limitation.

Other than the steepness, one consequence of differing $\mathrm{K}_{\mathrm{P}}$ is that simulated cyanobacteria reach maximum growth at very different levels of phosphate. SCOBI and ECOSM reach full growth already at very low phosphate concentrations, while CEMBS and ERGOM need much higher phosphate values to reach maximum growth - higher not only compared to the other models, but also relative to their respective other functional groups.

Common to all models considered here is that the cyanobacteria are never limited by the availability of 
Table 2. Description and units of the ecosystem model parameters considered in this study. The focus is on those parameters that differ among the different functional groups.

\begin{tabular}{lll}
\hline Parameter & Description & Unit \\
\hline$\mu$ & Max. phytoplankton growth rates & $\mathrm{d}^{-1}$ \\
\hline $\begin{array}{l}\mathrm{K} \\
\text { mot }\end{array}$ & Half-saturation constant for phosphate & $\mathrm{mmol} \mathrm{P} \mathrm{m}^{-3}$ \\
\hline mot $_{\text {quad }}$ & Linear phytoplankton mortality & $\mathrm{d}^{-1}$ \\
\hline$\sigma$ & Quadratic phytoplankton mortality & $\mathrm{d}^{-1}\left(\mathrm{mmol} \mathrm{P} \mathrm{m}^{-3}\right)^{-1}$ \\
\hline$a_{i}$ & Max. zooplankton grazing & $\mathrm{d}^{-1}$ \\
& Food preference per functional type $i=1,2,3$ & Unitless \\
\hline sinki & (optionally multiplied to $\sigma)$ & \\
\hline
\end{tabular}

Table 3. Key model parameters impacting cyanobacteria growth and sinking rates of phytoplankton put into relation to the respective parameters of other functional groups. All models include three functional phytoplankton groups, including cyanobacteria and diatoms. The third functional group, however, is called "flagellates" in ECOSMO, ERGOM, and SCOBI, while BALTSEM refers to the third functional group as "summer species" and CEMBS as "small phytoplankton". Note that the ERGOM model uses a modified Michaelis-Menten formulation and the half-saturation constants are thus not directly comparable to the other models. For models which include temperature dependence (Fig. 1), the values provided refer to $0^{\circ} \mathrm{C}$ (BALTSEM). Note that, as a peculiarity, the BALTSEM models use different sinking rates for diatoms in spring and autumn, and the sinking speed also depends on temperature, environmental conditions, and morphology. Also, the half-saturation constants for the BALTSEM model and the maximum growth rates of the CEMBS model are unit-converted from the original values. The bold text refers to cyanobacteria.

\begin{tabular}{lrrl}
\hline Model & $\begin{array}{r}\mu(\text { cyan.; } \\
\text { diatoms; others) }\end{array}$ & $\begin{array}{r}K_{P}(\text { cyan.; } \\
\text { diatoms; others) }\end{array}$ & $\begin{array}{l}\text { sinki (cyan.; } \\
\text { diatoms; others })\end{array}$ \\
\hline BALTSEM & $\mathbf{1 . 0} ; 1.3 ; 0.9$ & $\mathbf{0 . 0 5} ; 0.1 ; 0.05$ & $\mathbf{0 . 1} ; 0.5 / 0.1 ; 0.1$ \\
CEMBS & $\mathbf{0 . 3 3} ; 1.31 .3$ & $\mathbf{0 . 5} ; 0.1 ; 0.05$ & not provided \\
ECOSMO & $\mathbf{1 . 0} ; 1.3 ; 1.1$ & $\mathbf{0 . 0 5} ; 0.05 ; 0.05$ & $\mathbf{- 0 . 1} ; 0.0 ; 0.0$ \\
ERGOM & $\mathbf{0 . 5} ; 1.0 ; 0.7$ & $\mathbf{0 . 5} ; 0.3 ; 0.15$ & $\mathbf{- 0 . 1} ; 0.5,0.0$ \\
SCOBI & $\mathbf{1 . 0} ; 1.3 ; 0.9$ & $\mathbf{0 . 0 5} ; 0.1 ; 0.05$ & $\mathbf{0 . 0} ; 0.5 ; 0.1$ \\
\hline
\end{tabular}

bioavailable nitrogen (one exception being cyanobacteria below the surface in ECOSMO). The fixation of nitrogen is coupled to the uptake of phosphate in all models. In the absence of ammonium and nitrate, the models top up their intracellular nitrogen concentrations until a predefined $\mathrm{N}$ : P Redfield ratio is met. BALTSEM is a more complex flavour of this rule, by changing the intracellular $\mathrm{N}: \mathrm{P}$ ratios depending on the environmental conditions (water temperature, ratio of ambient $\mathrm{N}: \mathrm{P}$ concentrations and phosphate concentrations).

Despite the differences among the model formulations outlined above, all models agree in that cyanobacteria have an advantage over other functional groups under nitratedepleted conditions - if phosphate is available. This phosphate, which has no Redfield equivalent of bioavailable nitrogen, is also referred to as excess phosphate. In summary, all models agree in that excess phosphate promotes a cyanobacteria bloom.

Besides the impact of temperature and phosphorus limitation, there is consensus that the availability of light is essential to the growth of cyanobacteria. Details, however, differ: in BALTSEM, ERGOM, and SCOBI light limitation

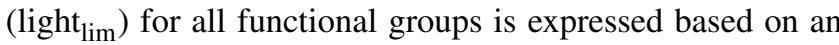
assumed optimal light level $\left(I_{\mathrm{opt}}\right)$ :

$\operatorname{light}_{\text {lim }}=I_{\mathrm{PAR}} / I_{\mathrm{opt}} \cdot \exp \left(1-\frac{I_{\mathrm{PAR}}}{I_{\mathrm{opt}}}\right)$.

$I_{\text {PAR denotes the incoming photosynthetically available ra- }}$ diation (PAR) in the respective depth layer. $I_{\mathrm{opt}}$ is set to $50 \mathrm{~W} \mathrm{~m}^{-2}$ in BALTSEM and $25 \mathrm{~W} \mathrm{~m}^{-2}$ in SCOBI.

ECOSMO and CEMBS, in contrast, assume that the light requirement for cyanobacteria is higher than for other functional groups. This considers that nitrogen fixation is an energetically expensive process which has to break the dinitrogen molecule and thus has to overcome the strongest atom-to-atom bond among all bonds involving two atoms. In ECOSMO a threshold, exclusive to cyanobacteria, of $120 \mathrm{~W} \mathrm{~m}^{-2}$, shuts down all growth when undercut. In CEMBS the formulation of differing light sensitivities for the respective functional groups is more complex: built on a modification (which directly includes a calculation of self- 
shading effects) of the classical approach which expresses light limitation based on a PI curve (light lim $_{1}=1-\exp (-\alpha$. PAR)), CEMBS prescribes different initial slopes for each of the functional groups. The lowest initial slope, $\alpha=0.17$, is prescribed for cyanobacteria, while the 0.3 and 0.34 for diatoms and small phytoplankton, respectively, imprint a higher competitiveness under low-light conditions. On a side note (which does not affect the competition between cyanobacteria and other functional groups in each of the respective models), the formulations, describing light attenuation within the water column, differ substantially among the models: BALTSEM accounts for shading effects of autotrophs, heterotrophs, and detritus, while ECOSMO only accounts for autotrophs. In addition, the attenuation coefficients of photosynthetically available radiation in seawater itself vary by almost a factor of 3 from one model to another.

Indirectly related to the formulation of light limitation is the representation of cyanobacteria's capabilities to control their buoyancy. Some species have gas vacuoles which give them the means to move upwards to the sunlit surface or prevent them from being moved downwards. The respective model formulations, however, vary considerably: in the ERGOM and ECOSMO models cyanobacteria have an advantage over other functional groups as they are positively buoyant and are, hence, less likely to be subducted into dark ocean layers. In SCOBI the simulated cyanobacteria do not sink, while other phytoplankton do. In BALTSEM the sinking speed of cyanobacteria is identical to other summer species (cf. Table 3).

\subsection{Loss terms for cyanobacteria}

Even more uncertain than the source terms are the sinks of cyanobacteria. The models generally assume some phytoplankton mortality, which can depend linearly and/or quadratically on the respective standing phytoplankton stocks. These fixed rates mimic complex processes, such as bacterial and viral lysis. In most considered models these parameters differ very little among functional groups (Table 4). Exceptions are BALTSEM and CEMBS: in the BALTSEM model the mortalities of the phytoplankton functional groups follow different temperature dependencies. In the CEMBS model the mortalities differ among functional groups: cyanobacteria have a slightly higher linear mortality than other functional groups, while a quadratic phytoplankton mortality is set to zero only for cyanobacteria. Generally, these constant rates of phytoplankton mortality are set to rather small values and thus typically receive only little attention. Even so, we want to note that this is of importance because the mortality determines the steady-state solutions and, related, can drastically determine ecosystem responses to eutrophication (Löptien, 2011).

The largest loss term, however, is typically zooplankton grazing. The knowledge and process understanding of this component are still limited and the assumptions between models differ widely. Typically, this formulation is nonlinear since the development of zooplankton biomass depends on its biomass. Another prerequisite for zooplankton growth or, rather, increase in its own biomass is food availability. Here, the different models consider different potential food sources and use very different additional constraints: for example, the ECOSMO model differentiates two zooplankton groups (micro- and macro-zooplankton) and assumes that micro-zooplankton feeds on phytoplankton and detritus, while macro-zooplankton feeds additionally on microzooplankton. In contrast, the ERGOM model assumes that their single explicitly represented zooplankton group feeds only on phytoplankton. In ERGOM, as in BALTSEM and CEMBS, maximum grazing rates are temperature-dependent (Fig. 2), while SCOBI is the only model which assumes an oxygen dependency of the grazing rates. A comprehensive assessment of all these grazing formulations has not been published yet and is beyond the scope of this study. The major aim here is merely to compare those parameters and formulations, which differ among functional groups within the models. In this respect selective grazing is of major interest. A comparison of the maximum grazing rates of the (competing) functional groups is shown in Table 4 and Fig. 2. All the models assume that zooplankton prefers phytoplankton and avoids cyanobacteria if possible. The magnitude of this preferential grazing is, however, unclear. Most models assume that the preference for cyanobacteria is a factor of 2-3 lower than for other functional groups. ECOSMO is an exception, with especially high food preferences. As a peculiarity, in the BALTSEM model grazing rates depend additionally on the actual fixation rates, with higher nitrogen fixation rates reducing the grazing pressure on cyanobacteria.

\section{Current knowledge about cyanobacteria's biology}

\subsection{Growth}

The growth of cyanobacteria, like other photoautotrophic organisms, depends on the availability of nutrients and light and is, additionally, influenced by other abiotic factors, such as temperature and salinity. In the following subsections we discuss factors affecting the growth of cyanobacteria and highlight the differences between cyanobacteria and other phytoplankton.

\subsubsection{Maximum growth}

Generally, cyanobacteria are thought to have slow growth rates in comparison to eukaryotic phytoplankton cells (Butterwick et al., 2005; Hense and Beckmann, 2006; Lips and Lips, 2008; Rakko and Seppäälä, 2014; Paerl and Otten, 2013; Paerl, 2014; Vahtera et al., 2005). This assumption is also ingrained into the models (cf. Fig. 1). However, according to Reynolds (2006) and Foy (1980), who report rather similar maximal growth rates of cyanobacteria and micro- 
Table 4. Model parameters that determine the termination of cyanobacterial blooms. Comparison among the models and respective parameters of other functional groups. The phytoplankton mortality rates in BALTSEM depend on temperature and the environmental conditions. The provided values refer to $0^{\circ} \mathrm{C}$. Also, the BALTSEM model uses different parameter values for diatoms in spring and autumn. The provided values for $\sigma$ for the ECOSMO and SCOBI models result from the product of max. zooplankton growth rate and food preference for the respective phytoplankton functional groups. The two values for the ECOSMO model refer to their two zooplankton groups: macro- and micro-zooplankton. The quadratic mortality for the CEMBS model was unit converted relative to the original values.

\begin{tabular}{lrrr}
\hline Model & $\begin{array}{r}\sigma(\text { cyan.; } \\
\text { diatoms; other })\end{array}$ & $\begin{array}{r}\text { Phyt. mot (cyan.; } \\
\text { diatoms; other })\end{array}$ & $\begin{array}{r}\text { Phyt. mot }{ }_{\text {quad }}(\mathbf{c y a n} . ; \\
\text { diatoms; other })\end{array}$ \\
\hline BALTSEM & $\mathbf{0 . 3} ; 1.0 / 0.0 ; 0.7$ & $\mathbf{0 . 4} ; 0.6 / 0.3 ; 0.4$ & - \\
\hline CMEBS & $\mathbf{0 . 9} ; 1.95 ; 2.5$ & $\mathbf{0 . 1 7} ; 0.15 ; 0.15$ & $\mathbf{0 . 0} ; 0.03 ; 0.03$ \\
\hline ECOSMO & $\begin{array}{r}\mathbf{0 . 0 9} / \mathbf{0 . 0 9} ; 0.25 / \\
0.68 ; 0.7 / 0.08\end{array}$ & $\mathbf{0 . 0 8} ; 0.05 ; 0.08$ & - \\
\hline ERGOM & $\mathbf{0 . 2 5} ; 0.5 ; 0.5$ & $\mathbf{0 . 0 2} ; 0.02 ; 0.02$ & - \\
\hline SCOBI & $\mathbf{0 . 0 3} ; 0.09 ; 0.105$ & $\mathbf{0 . 0 5} ; 0.05 ; 0.05$ & - \\
\hline
\end{tabular}

(a)

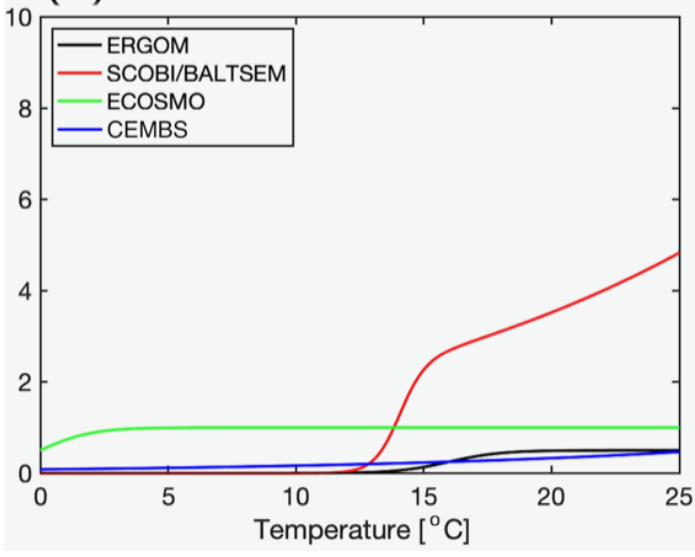

(b)

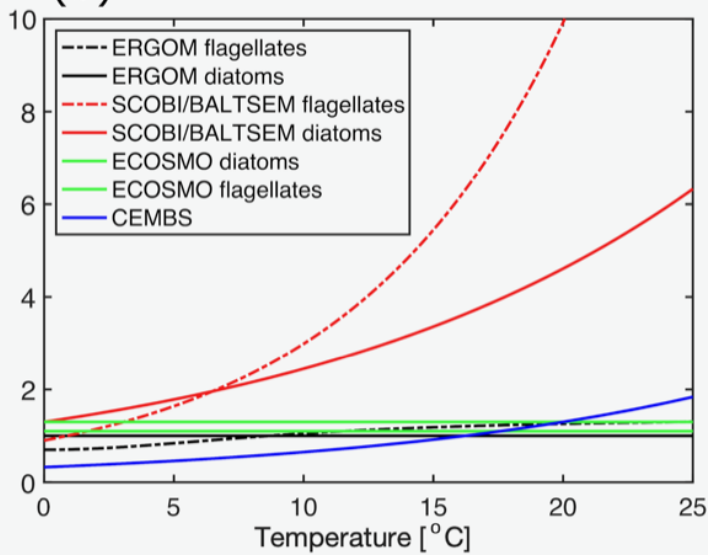

Figure 1. (a) Temperature dependence of the maximum growth for (a) cyanobacteria and for (b) other functional groups in the five considered biogeochemical models $\left(\mathrm{d}^{-1}\right)$.

algae, this assumption must be considered with some caution. Based on a study of 16 phytoplankton species (among others Aphanizomenon flos-aquae and Dolichospermum flos-aquae, which are rather common also in the Baltic Sea), Reynolds (2006) states that the maximal growth rates differ so substantially from species to species (even within functional groups) that generic statements about the functional groups cannot be made. The study by Foy (1980) explores 22 strains of 3 cyanobacteria genera (Aphanizomenon, Dolichospermum sp., and Oscillatoria). He draws the conclusion that algal size and shape appear to be better predictors of growth rates than the affiliation to a specific functional group. This statement is supported by the fact that many cellular functions are strongly governed by the surface-area-to-volume ratio (Kruk et al., 2010; Lewis , 1976). Further support showing similar results comes from Lürling et al. (2013), who tested eight different cyanobacteria and eight chlorophyte species (among others Aphanizomenon gracile and Dolichospermum sp.). Tables 5 and 6 summarize published maximum growth rates of the main cyanobacteria species in the Baltic Sea along with those of a choice of ordinary phytoplankton species. Indeed, we find maximum growth rates that differ substantially from one cyanobacteria species to another, and even among strains (Table 5). On average however these studies report somewhat slower growth rates for the three cyanobacteria species than e.g. for chlorophytes (Tables 5 and 6).

- For Aphanizomenon flos-aquae maximal growth rates of 0.18-1.34 d $\mathrm{d}^{-1}$ are reported (Foy, 1980; Gotham and Rhee, 1981; Rhee and Lederman, 1983; Konopka and Brock, 1978; Lee and Rhee, 1997, 1999; Sommer, 1981; Rakko and Seppäälä, 2014; Robarts and Zohary, 1987).

- Dolichospermum sp. shows maximal growth rates of 0.4-1.27 $\mathrm{d}^{-1}$ (Foy et al., 1976b; Konopka and Brock, 
(a)

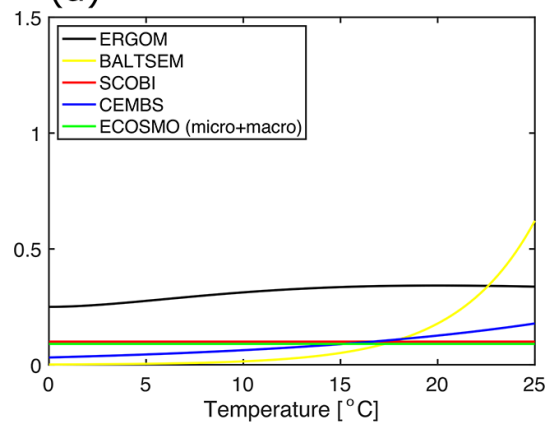

(b)

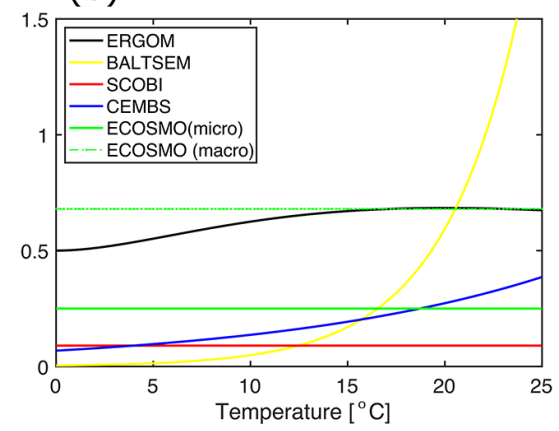

(c)

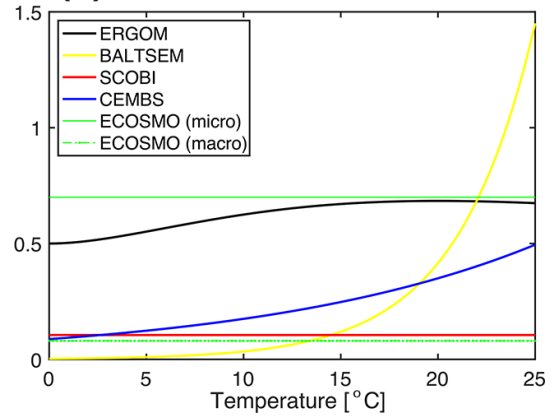

Figure 2. Maximum grazing rates in dependence of temperatures for (a) cyanobacteria, (b) diatoms, and (c) other phytoplankton ( $\left.\mathrm{d}^{-1}\right)$. Note that the BALTSEM model prescribes zero grazing of diatoms in autumn. The values for the ECOSMO and SCOBI models refer to the product of max. zooplankton growth rate and food preference for the respective phytoplankton functional groups and the temperature effect. The two values for the ECOSMO model refer to their two zooplankton groups: micro- and macro-zooplankton. All parameter values refer to the respective references provided in Table 4 . Note that the link to phytoplankton biomass differs considerably between the models, and a direct comparison of the curves is not necessarily straightforward.

1978; Lürling et al., 2013; Nalewajko and Murphy, 2001; Reynolds, 2006; Oh et al., 1991; Sommer, 1981; Tang et al., 1997).

- Measured maximal growth rates of Nodularia spumigena range from 0.13 to $0.6 \mathrm{~d}^{-1}$ (Cirés and Ballot, 2016; Lehtimäki et al., 1997; Sommer et al., 2006).

Maximum growth is only reached under optimal conditions that are rarely encountered in reality. In the following we explore the processes that inhibit maximum growth, such as nutrient depletion, high light intensities, and suboptimal temperatures.

\subsubsection{Temperature dependency}

In terms of temperature dependency, the model formulations differ widely, and some models (e.g. SCOBI and BALTSEM) assume that cyanobacteria require higher temperatures than ordinary phytoplankton for optimal growth (Fig. 1). The respective model assumptions are roughly in agreement with experimental work: while cyanobacteria species typically have optimal growth at higher temperatures than dinoflagellates or diatoms (Paerl et al., 2011), there are only small differences between cyanobacteria and green algae (Lürling et al., 2013). However, there is considerable variation between species. Butterwick et al. (2005) report that differences between algal species appear mainly at temperatures below 10 and above $25^{\circ} \mathrm{C}$ when testing the growth rate of 21 species within a temperature range between 2 and $35^{\circ} \mathrm{C}$. Also, Foy (1980) reports that the temperature optima of cultured Aphanizomenon flos-aquae and Dolichospermum sp. and others were similar to those of other planktonic autotrophs.

Regarding the typical Baltic Sea species, Table 7 shows optimal temperature ranges for the growth of the cyanobacteria species compared to other phytoplankton species. In the following we summarize the respective results.
- Aphanizomenon flos-aquae has a somewhat wider optimal temperature range than Nodularia spumigena, spanning from 16 to $31^{\circ} \mathrm{C}$ (Bugajev et al., 2015; Carey et al., 2012; Robarts and Zohary, 1987; Paerl and Otten, 2013; Degerholm et al., 2006). Temperatures which permit some growth are considerably lower than the optimal temperatures: Cirés and Ballot (2016) report that Aphanizomenon flos-aquae is able to grow at temperatures down to $10^{\circ} \mathrm{C}$. Üveges et al. (2012) measured intensive photosynthesis at even lower: $2-5^{\circ} \mathrm{C}$.

- For Dolichospermum sp. optimal temperatures for maximal growth lie between 18 and $25^{\circ} \mathrm{C}$. Growth starts at $10^{\circ} \mathrm{C}$, as reported by Hellweger et al. (2016), Konopka and Brock (1978), Robarts and Zohary (1987), and Paerl and Otten (2013).

- Nodularia spumigena prefers $20-25^{\circ}$ for optimal growth (Degerholm et al., 2006). Growth starts at $5^{\circ} \mathrm{C}$ (Nordin et al., 1980).

\subsubsection{Nutrient demands}

Because diazotrophs are able to fix atmospheric nitrogen, bioavailable phosphorus is regarded as the essential limiting nutrient in the Baltic Sea for diazotrophic cyanobacteria (where iron and molybdenum are generally sufficiently available). Note, however, that $\mathrm{N}_{2}$ fixation is a very energydemanding process which has the potential to reduce the growth rates by a factor of up to 2 or 3 (Hense and Beckmann, 2006; Rhee and Lederman, 1983; Paerl et al., 2006). Too low phosphate concentrations can prevent any growth.

Phosphate $(\mathrm{P})$ is essential, i.a. for cellular synthesis of nucleic acids, membrane phospholipids, as well as for energy transfer through tri- and bi-phosphorylated nucleotides (Degerholm et al., 2006). All models agree that the availabil- 
Table 5. Maximal growth rates $(\mu)$ of the studied cyanobacteria species.

\begin{tabular}{llrl}
\hline Class & Species & $\mu$ & Reference \\
\hline Cyanobacteria & Aphanizomenon flos-aquae & 0.39 & Foy et al. (1976b) \\
Cyanobacteria & Aphanizomenon flos-aquae & 0.89 & Gotham and Rhee (1981) \\
Cyanobacteria & Aphanizomenon flos-aquae & $0.95-1.34$ & Rhee and Lederman (1983) \\
Cyanobacteria & Aphanizomenon flos-aquae & 0.99 & Lee and Rhee (1999) \\
Cyanobacteria & Aphanizomenon flos-aquae & 0.43 & Sommer (1981) \\
Cyanobacteria & Aphanizomenon flos-aquae & 0.89 & Gotham and Rhee (1981) \\
Cyanobacteria & Aphanizomenon flos-aquae & $0.28-0.31$ & Rakko and Seppäälä (2014) \\
Cyanobacteria & Aphanizomenon flos-aquae & $0.25-0.75$ & Lee and Rhee (1997) \\
Cyanobacteria & Aphanizomenon flos-aquae & 0.18 & Konopka and Brock (1978) \\
Cyanobacteria & Aphanizomenon flos-aquae & 1.2 & Robarts and Zohary (1987) \\
Cyanobacteria & Dolichospermum sp. & 0.51 & Foy et al. (1976b) \\
Cyanobacteria & Dolichospermum sp. & 0.41 & Sommer (1981) \\
Cyanobacteria & Dolichospermum sp. & 0.78 & Reynolds (2006) \\
Cyanobacteria & Dolichospermum sp. & $0.4-1.1$ & Tang et al. (1997) \\
Cyanobacteria & Dolichospermum sp. & $0.94-1.27$ & Oh et al. (1991) \\
Cyanobacteria & Dolichospermum sp. & 0.93 & Lürling et al. (2013) \\
Cyanobacteria & Dolichospermum sp. & 0.4 & Konopka and Brock (1978) \\
Cyanobacteria & Dolichospermum sp. & 1.25 & Nalewajko and Murphy (2001) \\
Cyanobacteria & Nodularia spumigena & $0.14-0.16$ & Rakko and Seppäälä (2014) \\
Cyanobacteria & Nodularia spumigena & $0.2-0.6$ & Sommer et al. (2006) \\
Cyanobacteria & Nodularia spumigena & 0.13 & Lehtimäki et al. (1997) \\
& & &
\end{tabular}

Table 6. Maximal growth rates $(\mu)$ of different phytoplankton groups.

\begin{tabular}{llrl}
\hline Class & Species & $\mu$ & Reference \\
\hline Green algae & Chlamydomonas reinhardtii & $3.3-3.8$ & Hoogenhout and Amesz (1965) \\
Green algae & Chlorella luteoviridis & 0.56 & Hoogenhout and Amesz (1965) \\
Green algae & Chlorella strain 221 & 1.84 & Reynolds (2006) \\
Green algae & Eudorina unicocca & 0.62 & Reynolds and Rodgers (1983) \\
Green algae & Scenedesmus sp. & 1.35 & Gotham and Rhee (1981) \\
Green algae & Volvox aureus & 0.46 & Reynolds (2006) \\
Green algae & Eight species & -1.38 & Lürling et al. (2013) \\
Dinoflagellates & Ceratium furcoides & 0.29 & Butterwick et al. (2005) \\
Dinoflagellates & Ceratium hirundinella & 0.21 & Reynolds (2006) \\
Diatoms & Asterionella formosa & $1.9-2.4$ & Hoogenhout and Amesz (1965) \\
Diatoms & Asterionella formosa & 1.78 & Lund (1949) \\
Diatoms & Asterionella formosa & 1.78 & Lund (1949) \\
Diatoms & Asterionella formosa & 0.67 & Holm and Armstrong (1981) \\
Diatoms & Chaetoceros gracilis & $>3.1$ & Lund (1979) \\
Diatoms & Cyclotella nana & 1.6 & Fuhs (1972) \\
Diatoms & Cyclotella nana & 3.4 & Hoogenhout and Amesz (1965) \\
Diatoms & Fragilaris crotonensis & 0.90 & Gotham and Rhee (1981) \\
Diatoms & Fragilaris crotonensis & 1.37 & Reynolds (2006) \\
Diatoms & Nitzschia actinastroides & 1.5 & Lund (1979) \\
Diatoms & Skeletonema costatum & 4.3 & Hoogenhout and Amesz (1965) \\
Diatoms & Staphanodiscus hantzschii & 1.7 & Hoogenhout and Amesz (1965) \\
Diatoms & Thalassiosira fluviatilis & 1.6 & Fuhs (1972) \\
\hline & & \\
\hline & & & \\
& & &
\end{tabular}


Table 7. Optimal temperature ranges for growth of different phytoplankton groups.

\begin{tabular}{llrl}
\hline Class & Species & ${ }^{\circ}$ C & Reference \\
\hline Cyanobacteria & Aphanizomenon flos-aquae & $18-22.5$ & Tang et al. (1997) \\
Cyanobacteria & Aphanizomenon sp. & $16-22$ & Lehtimäki et al. (1994) \\
Cyanobacteria & Aphanizomenon sp. & 25 & Konopka and Brock (1978) \\
Cyanobacteria & Aphanizomenon gracile & 32.5 & Lürling et al. (2013) \\
Cyanobacteria & Dolichospermum sp. & $18-35$ & Tang et al. (1997) \\
Cyanobacteria & Dolichospermum sp. & 25 & Lürling et al. (2013) \\
Cyanobacteria & Dolichospermum sp. & 25 & Konopka and Brock (1978) \\
Cyanobacteria & Dolichospermum sp. & $28-32$ & Nalewajko and Murphy (2001) \\
Cyanobacteria & Nodularia sp. & $20-25$ & Lehtimäki et al. (1994) \\
Cyanobacteria & Nodularia sp. & $25-30$ & Nordin et al. (1980) \\
Cyanobacteria & Nodularia sp. & $25-30$ & Lehtimäki et al. (1997) \\
Green algae & Ankistrodesmus falcatus & 32.5 & Lürling et al. (2013) \\
Green algae & Chlamydomonos reinhardtii & 27.5 & Lürling et al. (2013) \\
Green algae & Desmodesmus bicellularis & 35 & Lürling et al. (2013) \\
Green algae & Desmodesmus quadricauda & 32.5 & Lürling et al. (2013) \\
Green algae & Monoraphidium minutum & 27.5 & Lürling et al. (2013) \\
Green algae & Scenedesmus acuminatus & 27.5 & Lürling et al. (2013) \\
Dinoflagellates & Ceratium furcoides & 20 & Butterwick et al. (2005) \\
Diatoms & Chaetoceros socialis & 18 & Eppley (1977) \\
Diatoms & Skeletonema costatum (3 studies) & $16-30$ & Eppley (1977) \\
Diatoms & Thalassiosira nordenskiolldii & $11-14$ & Eppley (1977) \\
\hline
\end{tabular}

ity of phosphate is an essential precondition for cyanobacteria growth. The models do, however, differ considerably in terms of which $\mathrm{P}$ concentrations become limiting for the growth of cyanobacteria. The respective values for the halfsaturation constants envelope a large range from 0.05 to $0.5 \mathrm{mmol} \mathrm{P} \mathrm{m}^{-3}$ (cf. Table 3). Apart from the CEMBS model, this range is comparable to phytoplankton in all of the models investigated here.

Similar to this, laboratory experiments also show a huge range for the half-saturation constant. Table 8 shows that cyanobacteria can keep up with dinoflagellates and some green algae for P. Some cyanobacteria species have been shown to feature a very high affinity for the uptake of $\mathrm{P}$ because they are able to rapidly increase their $P$ uptake rate by upregulating two high-affinity P-binding proteins and phosphatase (Cottingham et al., 2015; Gobler et al., 2016). Additional adjustments to low $\mathrm{P}$ conditions include a reduction of their overall $\mathrm{P}$ requirements by substituting P-containing lipids with alternatives. There is also evidence that cyanobacteria have relative low P requirements (Kononen and Leppänen, 1997; Degerholm et al., 2006). Even so, Moisander et al. (2007) show in field and laboratory experiments that P addition typically stimulates growth and nitrogen-fixation rates of Aphanizomenon sp. and Nodularia spumigena, which suggests that the availability of $\mathrm{P}$ is limiting in the Baltic Sea (despite the low $\mathrm{P}$ requirements). In this context Andersson et al. (2015a) found that Nostocales were dominating the cyanobacteria community under high total $\mathrm{P}$ and were negatively related to total N. Paerl and Otten (2016) show that $\mathrm{N}_{2}$-fixing cyanobacteria dominate more often under $\mathrm{N}$ - replete conditions, not under high-P and low-N conditions. So far there is no consensus on whether the concentrations of $\mathrm{P}$ or $\mathrm{N}$ or the relationship of $\mathrm{N}: \mathrm{P}$ favour dominance of cyanobacteria.

The minimum P requirements are species-dependent: Aphanizomenon flos-aquae seems to have somewhat higher $\mathrm{P}$ demands and literature values for the half-saturation constant range from 1 to $2.5 \mathrm{mmol} \mathrm{P} \mathrm{m}^{-3}$ (Degerholm et al., 2006; Gotham and Rhee, 1981; Healey et al., 1973). Olofsson et al. (2016) report that in the Baltic Sea P concentrations of $0.04 \mathrm{mmol} \mathrm{P} \mathrm{m}^{-3}$ can limit Nodularia spumigena growth. Degerholm et al. (2006) indicate half-saturation constants of $1-1.7 \mathrm{mmol} \mathrm{P} \mathrm{m}^{-3}$ for Nodularia spumigena (Table 8). For comparison, e.g. Reynolds (2006) reports much higher values up to $5.24 \mathrm{mmol} \mathrm{P} \mathrm{m}^{-3}$ for some green algae, while the investigated diatoms seem to have rather low $\mathrm{P}$ demands. The listed half-saturation constants for diatoms in Table 8 range from 0.12 to $1.72 \mathrm{mmol} \mathrm{Pm}^{-3}$ (Fuhs, 1972; Lund, 1979; Holm and Armstrong, 1981; Yamamoto et al., 2012).

An interpretation of these studies is complicated by the ability of cyanobacteria to access dissolved organic phosphorus (DOP) besides DIP. Phosphate $\left(\mathrm{PO}_{4}^{-3}\right)$ is the dominant form of DIP in natural waters and directly bioavailable for plants. In contrast, DOP is an integral part of the marine organic matter pool. DOP exists in a variety of forms which result from death and autolysis of organisms, decomposition, and excretion. Phosphorus esters $(75 \%)$ and phosphonates $(25 \%)$ are the two dominant forms of oceanic DOP (Clark et al., 1998). Not all phytoplankton possess alkaline phos- 
Table 8. Half-saturation constant for phosphate $\left(K_{P}\right)$ for different phytoplankton groups.

\begin{tabular}{|c|c|c|c|}
\hline Phylum & Species & $\begin{array}{r}\mathrm{K}_{\mathrm{P}} \\
\left(\mathrm{mmol} \mathrm{Pm}^{-3}\right)\end{array}$ & Reference \\
\hline Cyanobacteria & Aphanizomenon flos-aquae $e^{1,2, a}$ & 1.13 & Gotham and Rhee (1981) \\
\hline Cyanobacteria & Aphanizomenon flos-aquae 1,2, a & 2.5 & Degerholm et al. (2006) \\
\hline Cyanobacteria & Anabaena variabilis 1,2, a & $1-2$ & Healey et al. (1973) \\
\hline Cyanobacteria & Dolichospermum sp. ${ }^{1, \mathrm{a}}$ & $1.8-2.5$ & Reynolds (2006) \\
\hline Cyanobacteria & Microcystis aeruginos $a^{1, \text { a }}$ & 1.23 & Holm and Armstrong (1981) \\
\hline Cyanobacteria & Microcystis sp. 1, a & 2.11 & Gotham and Rhee (1981) \\
\hline Cyanobacteria & Nodularia spumigena $^{2, \text { a }}$ & $1.0-1.7$ & Degerholm et al. (2006) \\
\hline Green algae & Chlorella pyrenoidosa $a^{1,2, \mathrm{~b}}$ & 0.68 & Nyholm (1977) \\
\hline Green algae & Scenedesmus sp. $1,2, \mathrm{c}$ & $0.57 / 3.4$ & Gotham and Rhee (1981) \\
\hline Green algae & Volvox aureus $4, \mathrm{c}$ & 5.24 & Reynolds (2006) \\
\hline Dinoflagellates & Alexandrium tamarense $e^{3,4, b, c}$ & 2.6 & Yamamoto et al. (2012) \\
\hline Dinoflagellates & Gymnodinium catenatum ${ }^{4, \mathrm{a}, \mathrm{b}}$ & 3.4 & Yamamoto et al. (2012) \\
\hline Dinoflagellates & Peridinium sp. ${ }^{2-4, \mathrm{~b}}$ & 0.11 & Reynolds (2006) \\
\hline Dinoflagellates & Pyrocystis noctiluca $a^{3,4, \mathrm{~b}}$ & 2.1 & Rivkin and Swift (1982) \\
\hline Diatoms & Asterionella formosa $a^{1, \mathrm{c}}$ & 0.70 & Holm and Armstrong (1981) \\
\hline Diatoms & Chaetoceros gracilis $1, \mathrm{a}, \mathrm{b}$ & 0.12 & Lund (1979) \\
\hline Diatoms & Cyclotella nana ${ }^{1,2, \mathrm{a}, \mathrm{c}}$ & 0.58 & Fuhs (1972) \\
\hline Diatoms & Nitzschia actinastroides $1, \mathrm{c}$ & 0.013 & Lund (1979) \\
\hline Diatoms & Skeletonema costatum 1,2 , a & 0.68 & Yamamoto et al. (2012) \\
\hline Diatoms & Thalassiosira fluviatilis ${ }^{3,4, \mathrm{~b}}$ & 1.72 & Fuhs (1972) \\
\hline
\end{tabular}

Please note that different size classes of algae are indicated by numbers $\left({ }^{1}\right.$ tiny; ${ }^{2}$ small; ${ }^{3}$ medium; ${ }^{4}$ large $)$ and by letter ( ${ }^{\mathrm{a}}$ chains; $\mathrm{b}$ single; ${ }^{\mathrm{c}}$ other).

phatase and can use DOP. From those that can use DOP, the efficiency of using DOP differs. While e.g. dinoflagellates grow well under a variety of DOP compounds, diatoms show a much lower and more restricted DOP utilization (Wang et al., 2011). By being able to use a variety of DOP compounds, cyanobacteria have a considerable advantage over other phytoplankton species, which are restricted to DIP or phosphorus esters (Degerholm et al., 2006; Dyhrman et al., 2006; Sohm and Capone, 2006; Paerl, 2014). Phytoplankton that is able to use DOP most commonly uses alkaline phosphatase (AP) to hydrolyse phosphorus esters (Lin et al., 2012, 2016). Some phytoplankton species also have the potential to utilize phosphonates of the DOP compounds, which are harder to extract for P (Dyhrman et al., 2006). This has been shown for many cyanobacteria species. They are able to access the more refractory phosphonates as well as the semilabile phosphorus esters (Sohm et al., 2008; Orchard et al., 2010; Orcutt et al., 2013; Whitton et al., 1991; Dyhrman et al., 2006; O’Neil et al., 2012).

In accordance with this, various studies support an efficient use of DOP by cyanobacteria species of the Baltic Sea. Degerholm et al. (2006) show with their experimental work that under limitation of DIP Dolichospermum sp. as well as Nodularia spumigena increase their alkaline phosphatase (APase) activity. This indicates that these two cyanobacteria species are able to use DOP for their growth. Degerholm et al. (2006) assumed that Nodularia spumigena's high uptake ability for DOP enables Nodularia spumigena to tolerate DIP limitation during summer months. Studies of O'Neil et al. (2012) and Vahtera et al. (2007b) support the finding of Degerholm et al. (2006). Schoffelen et al. (2018) investigate single-cell P-uptake rates with nanoSIM (nanometrescale secondary ion mass spectrometry). Their measurements show that Aphanizomenon sp. acquired only $15 \%$ of its $\mathrm{P}$ demand from DIP and used instead about $85 \%$ from DOP. However, there are also conflicting results: in Vahtera et al. (2007b) experiments Aphanizomenon sp. was not able to use DOP. Also, in Schoffelen et al. (2018) Nodularia spumigenas almost exclusively used DIP for its growth even at very low phosphate concentrations, while Dolichospermum sp. showed an intermediate behaviour. Note in this context that models generally do not consider DOP to be an additional prognostic variable.

Another factor, which is rarely considered in models (an exception is BALTSEM), is the storage capacity of DIP by cyanobacteria. It is well known that some cyanobacteria are able to drastically increase their intracellular $\mathrm{P}$ concentration (Nausch et al., 2008; Walve and Larsson, 2007, 2010; Sohm et al., 2011) and to store excess DIP. For the Baltic Sea this has been shown for Aphanizomenon sp. (Larsson et al., 2001). In May, after the spring bloom, Aphanizomenon sp. showed $\mathrm{C}: \mathrm{P}$ ratios around 50 (Redfield, 1958, C : P = 
106 : 1). Nausch et al. (2009) even measured a $\mathrm{C}: \mathrm{P}$ ratio of 32 after an upwelling event. However, Larsson et al. (2001) observed that during the subsequent build-up of biomass, $\mathrm{P}$ is used for growth and cellular $\mathrm{P}$ concentrations are decreasing ( $\mathrm{C}: \mathrm{P}$ ratios around 400). Larsson et al. (2001) conclude that the growth rate of Aphanizomenon sp. is limited by DIP availability in the Baltic Sea. Also, Raateoja et al. (2011) and Wasmund et al. (2005) share the opinion that, despite their DIP storage capacity, additional P sources are needed to sustain today's observed cyanobacterial blooms in the Baltic Sea.

\subsubsection{Light limitation}

Cyanobacterial and algal photosynthesis rates are significantly influenced i.a. by the combination of light intensity and temperature (Butterwick et al., 2005). With increasing light intensity photosynthesis rate will increase until the saturation level is achieved (Ik) and the maximal photosynthesis rate $\left(P_{\max }\right)$ is reached. The initial slope of this photosynthesis-irradiance curve (alpha) describes the performance of both light-harvesting and photosynthetic conversion efficiency. Alpha is species-specific and rather temperature-independent over a wide range. Alpha is, however, a strong function of the highly variable carbon-specific chlorophyll $a$ content of cells owing to the central role of chlorophyll in photosynthesis.

$P_{\max }$, on the other hand, will be influenced i.a. by temperature. Below the temperature optima, $P_{\max }$ increases nonlinearly, roughly doubling with each $10^{\circ} \mathrm{C}$ rise in temperature until a threshold temperature (Reynolds, 2006). Beyond the threshold excessive temperatures in combination with prolonged exposure to high light intensities may cause photo-inhibition and induce harmful effects in algae (Ibelings, 1996). Photo-inhibition also occurs when phytoplankton is shifted to irradiance substantially above those to which they have been acclimatized. Cyanobacteria, however, can modify their photosynthetic apparatus within minutes to accommodate rapid fluctuations in light intensity or quality.

This basic concept that algal growth is influenced by light and temperature is captured by all the models considered here - although it comes in different flavours: ECOSMO and CEMBS assume that the light requirement for cyanobacteria is higher than for other functional groups, while the other models do not distinguish between functional groups here (cf. Sect. 2.2).

The species Nodularia spumigena and Aphanizomenon sp. seem to be well acclimated to relatively high PAR levels, especially at high temperatures (Śliwińska-Wilczewska et al., 2019). Their cell-specific $P_{\max }$ values were the highest in Nodularia spumigena and Aphanizomenon sp. strains grown under the lowest light intensity. Both species changed their chlorophyll $a$-specific alpha depending on environmental conditions. Maximum alpha values for Nodularia spumigena and Aphanizomenon sp. were found at low light, low temperature, and low salinity $\left(10 \mu \mathrm{mol}\right.$ photons $\mathrm{m}^{-2} \mathrm{~s}^{-1}$, $15^{\circ}$, and 8 PSU) (Śliwińska-Wilczewska et al., 2019). Similarly to this, DeNobel et al. (1998) found that for Aphanizomenon flos-aquae and Anabaena sp. their alpha increased with decreasing irradiance but was always higher for Aphanizomenon flos-aquae than for Anabaena sp. This was due to a higher chlorophyll $a$ content in cells of Aphanizomenon flos-aquae than in Anabaena sp.

The differences between species in terms of their optimal light requirements are substantial. In the following we summarize studies sorted by species. Table 9 refers to the individual studies.

- For Aphanizomenon flos-aquae optimal irradiance for photosynthesis is reported to be $6->33 \mathrm{~W} \mathrm{~m}^{-2}$ in laboratory and field experiments (Lehtimäki et al., 1997; Üveges et al., 2012). Photo-inhibition for Aphanizomenon flos-aquae was reported at a light intensity of $99 \mathrm{~W} \mathrm{~m}^{-2}$ (Pechar et al., 1987).

- According to Eigemann et al. (2018) and Walsby and Booker (1980), Dolichospermum sp. prefers rather low irradiance values of $4-8 \mathrm{~W} \mathrm{~m}^{-2}$.

- Several scientists tested the optimal light intensity for Nodularia spumigena. They state that Nodularia spumigena grows best at the highest light level tested (23$66 \mathrm{~W} \mathrm{~m}^{-2}$ ). Net growth was reported over a wide range of light intensities $5-114 \mathrm{~W} \mathrm{~m}^{-2}$ in laboratory experiments (Eigemann et al., 2018; Jodlowska and Latala, 2019; Lehtimäki et al., 1997; Nordin et al., 1980; Roleda et al., 2008). Nordin et al. (1980) observe that very high temperatures $\left(35^{\circ} \mathrm{C}\right)$ in combination with high light levels $\left(114 \mathrm{~W} \mathrm{~m}^{-2}\right)$ can prohibit the growth of Nodularia spumigena. Consistently, Jodlowska and Latala (2019) report reduced filament concentrations and reduced photosynthesis rates at a combination of high light intensities and high temperatures $\left(30^{\circ} \mathrm{C}\right)$. It is noteworthy that Jodlowska and Latala (2019) did not find any photo-inhibition of Nodularia spumigena until $153 \mathrm{~W} \mathrm{~m}^{-2}$.

\subsubsection{Buoyancy}

Many cyanobacteria possess buoyancy-regulation mechanisms, which enables them to actively control their position in the water column (Visser et al., 2016). Accordingly, the ERGOM and ECOSMO models assume that cyanobacteria are buoyant, while the SCOBI model applies a lower sinking speed for cyanobacteria than for other phytoplankton. All respective velocities are of the order of centimetres per day and do not change with light intensity or nutrient availability (Table 3).

In nature, buoyancy control is rather complex. Three control mechanisms that regulate buoyancy internally have been identified: (1) the organisms can modify the rate of gas 
Table 9. Optimal light levels $\left(\mathrm{W} \mathrm{m}^{-2}\right)$ for the studied cyanobacteria species.

\begin{tabular}{lrll}
\hline Species & $\mathrm{W} \mathrm{m}^{-2}$ & $\begin{array}{l}\text { Grow } \\
\text { condition }\end{array}$ & Reference \\
\hline All three species & 61.32 & Best & Śliwińska-Wilczewska et al. (2019) \\
Aphanizomenon flos-aquae & $6-10$ & Best & Lehtimäki et al. (1997) \\
Aphanizomenon flos-aquae & $>33$ & Best & Üveges et al. (2012) \\
Dolichospermum sp. & 8.32 & Best & Eigemann et al. (2018) \\
Dolichospermum sp. & 3.72 & Best & Walsby and Booker (1980) \\
Nodularia spumigena & 25 & Best & Nordin et al. (1980) \\
Nodularia spumigena & $5-114$ & Can grow & Nordin et al. (1980) \\
Nodularia spumigena & 32.85 & Best & Eigemann et al. (2018) \\
Nodularia spumigena & $23-34$ & Best & Lehtimäki et al. (1997) \\
Nodularia spumigena & 63.5 & Best & Jodlowska and Latala (2019) \\
Nodularia spumigena & 65.7 & Best & Roleda et al. (2008) \\
& & &
\end{tabular}

Table 10. Sinking/floating speeds of different cyanobacteria.

\begin{tabular}{llrl}
\hline Class & Species & $\mathrm{mm} \mathrm{d}^{-1}$ & Reference \\
\hline Cyanobacteria & Aphanizomenon flos-aquae & $3.5-5.2$ & Reynolds (2006) \\
Cyanobacteria & Aphanizomenon flos-aquae & 22 & Walsby et al. (1995) \\
Cyanobacteria & Aphanizomenon flos-aquae & $15.5-51.8$ & Adam (1999) \\
Cyanobacteria & Doliochospermum sp. & $3.5-5.2$ & Reynolds (2006) \\
Cyanobacteria & Dolichospermum sp. & $0.1-0.3$ & Walsby et al. (1995) \\
Cyanobacteria & Nodularia spumigena & 36 & Walsby et al. (1995) \\
Cyanobacteria & Nodularia spumigena & $35-45.7$ & Adam (1999) \\
\hline
\end{tabular}

vesicles being synthesized, (2) they can change their cell ballast by storage carbon which is produced by photosynthesis (mainly carbohydrates and proteins), and (3) under prolonged irradiance and high photosynthesis rates the intracellular turgor pressure in some species can increase, which leads to the collapse of gas vesicles (Kromkamp and Konopka, 1986; Konopka et al., 1987). An additional mechanism, related to Stoke's drag, is colony size, with bigger colonies accelerating faster in response to buoyancy changes.

Vertical mobility can be beneficial for cyanobacteria. For example, it was suggested that cyanobacteria can sink downwards to take up nutrients from deeper waters (Cottingham et al., 2015; Konopka et al., 1987; Paerl, 1988) or to avoid harmful irradiance levels. Ganf and Oliver (1982) show that cyanobacteria in shallow waters (Dolichospermum spiroides, Microcystis aeruginosa) can migrate sufficiently up and down the water column to reach nutrient-rich water despite substantial density barriers. Cyanobacteria are also reported to migrate upwards or downwards to reach an optimal level of irradiance for photosynthesis (Whitton and Potts, 2002; Ibelings et al., 1991; Walsby et al., 1997; Walsby and Booker, 1980). Thus, vertical migration might give them a crucial advantage over their competitors. On top of the euphotic zone, cyanobacteria can maximize their photosynthesis and nitrogen fixation and, additionally, they can shade their potential competitors. For example, Nodularia spumi- gena is adapted to very high irradiation levels and floats typically close to the water surface. Also, due to their buoyancy, cyanobacteria do not face the risk of sinking out of the euphotic zone like other phytoplankton.

The ability to migrate depends on size and morphology. Some cyanobacteria, like small Synechococcus sp. (without gas vesicles), can only migrate a few centimetres per day while others can cover several metres.

Listed below are the floating velocities for the considered cyanobacteria species of the Baltic Sea (Table 10 specifies the respective individual experiments).

- For Aphanizomenon flos-aquae very different floating velocities of 4-52 $\mathrm{m} \mathrm{d}^{-1}$ ? (Adam, 1999; Reynolds, 2006; Walsby et al., 1995) were measured. Walsby et al. (1995) also observed that the floating velocities of Aphanizomenon flos-aquae vary depending on light conditions, with higher velocities under low light.

- In comparison, Dolichospermum sp. is assumed to float much more slowly, as it does not form aggregates (Stal et al., 2003). Accordingly, Walsby et al. (1995) report respective floating velocities of $0.1-0.3 \mathrm{~m} / \mathrm{d}^{-1}$ for Dolichospermum sp. Note in this context that Dolichospermum sp. occurs mainly at a depth of 5-10 $\mathrm{m}$.

- In the Baltic Sea, Nodularia spumigena tends to float to the sea surface, and there is no evidence for large 
changes in floating velocities under varying light conditions (Adam, 1999). Recorded floating velocities range from 35 to $46 \mathrm{~m} \mathrm{~d}^{-1}$ for Nodularia spumigena colonies (Adam, 1999; Walsby et al., 1995).

Note that changes in buoyancy by gas vesicles is a slow process. The formation of gas vesicles generally takes more than a day (Oliver, 1994) and is a highly energetic process (Hense and Beckmann, 2006). It also requires nitrogen (Brookes et al., 2001; Klemer et al., 1982), and under phosphorus limitation the formation of gas vesicles has been shown to slow down (Konopka et al., 1987; Brookes et al., 2000). Some cyanobacteria possess rather rigid gas vesicles. Species from the open Baltic Sea are observed to have relatively strong gas vesicles, while inshore populations have generally weaker gas vesicles. According to (Sellner, 1997), the strong gas vesicles of Nodularia spumigena and Aphanizomenon flos-aquae can even survive, mixing down to $90 \mathrm{~m}$ depths. Cyanobacteria might, however, lose their buoyancy due to decreasing temperatures in autumn (Carey et al., 2012). Generally, colder water temperatures lead to a reduction in photosynthetic and respiratory rates and a much lower protein synthesis. Instead, glycogen is accumulated. This carbohydrate ballast results in the sinking of cyanobacterial cells (Visser et al., 1995; Thomas and Walsby, 1986).

\subsection{Loss terms}

There are a number of lethal threats for cyanobacteria cells: cell death can be caused by necrosis through adverse environmental conditions, such as insufficient light, nutrients, or temperature, or by a programmed cell death (PCD) (Franklin, 2013). Cells can be infected by fungi, undergo viral lysis (Munn, 2011), or be grazed by a diverse selection of zooplankton (Franklin, 2013). The following subsections list the various causes of cyanobacteria loss. Note that the biogeochemical models investigated in this study differentiate only grazing from other causes of cell losses. For all non-grazingrelated losses, the models generally assume a fixed loss rate which depends either linearly or quadratically on abundance. An exception is the BALTSEM model, where the mortality of phytoplankton depends on water temperature and is also inversely related to the Liebig minimum function (as a measure of unfavourable environmental conditions; cf. Sect. 2.3).

\subsubsection{Unfavourable environmental conditions}

Under unfavourable environmental conditions cyanobacteria cells are subject to increased cell loss: for example, Sigee et al. (2007) report for Microcystis flosaquae at least $20 \%-$ $50 \%$ senescent or dead cells by the end of summer. The necrosis of cyanobacteria cells can be due to an injury response to harmful environmental conditions (e.g. high irradiance levels, salt stress, chemical perturbation, oxidative stress, phosphate limitation, iron limitation, high $\mathrm{pH}$, low temperatures, and low irradiance levels) (Lee and Rhee,
1999; Sigee et al., 2007). Among the ones confirmed in the Baltic Sea are mixing events, low irradiance levels, nutrient limitation, and low temperatures (Vahtera et al., 2007a).

\subsubsection{PCD}

In contrast to necrosis, cell death can result from an active physiological response of a cell in response to negative environmental conditions - a PCD. There is growing evidence that PCD-like cell death can occur from unicellular amoebae and bacteria up to higher animals and plants (Ameisen, 1996). While the existence of PCD in cyanobacteria is still debated (Franklin, 2013), Claessen et al. (2014) show that several lines of evidence point to the occurrence of PCD in filamentous cyanobacteria. For example, individual cell death of Microcystis flosaquae occurs randomly throughout the colony and is unrelated to any infection or cell cycle (Sigee et al., 2007). Instead, the cells switch actively to PCD. Similar Trichodesmium sp. and different strains of Dolichospermum display typical symptoms of PCD-like morphological deformations, fragmentation, and the subsequent autolysis of cells when exposed to stress (Berman-Frank et al., 2004; Ning et al., 2002). For Dolichospermum flos-aquae Lee and Rhee (1999) state that cell death is controlled by circadian rhythms, which implies that cell death is programmed in these organisms. Another hypothesis is that PCD might be the result of asymmetric cell division (Franklin, 2013). For example, in Dolichospermum solitarium cell division always results in one large and one smaller cell. The larger cells act as a repository for metabolic waste, which will result in its early death, leading the smaller cell to a rejuvenation or increased fitness. All these studies indicate that PCD is part of the cyanobacterial life in the ocean and might be an important process in the decline of cyanobacteria blooms. Also, cell death by PCD may facilitate biogeochemical cycling through the regular death of cells by PCD and the resulting release of organic and inorganic matter, including the redistribution of fixed nitrogen (Berman-Frank et al., 2004).

\subsubsection{Infections and lysis - direct effects}

Cyanobacteria cells can be infected by various organisms or entities like fungi, bacteria, or viruses. However, it is difficult to calculate the net effect of the different infections because there are antagonistic effects between them.

\section{Fungi}

Depending on the geographic region, the Baltic Sea resembles either a freshwater or marine environment. The respective salinity threshold of fungi lies around 8 PSU. Depending on this classification, the fungi community structure typically differs strongly. In salinities below 8 PSU fungal infections of bacteria and cyanobacteria cells are common. For instance, Mohamed et al. (2014) show that the fungi Trichoderma citrinoviride could lyse Microcystis aeruginosa. Simi- 
larly Kozik et al. (2019) report cell death of Dolichospermum sp. colonies due to infection by chytrid fungi.

\section{Bacteria}

Many bloom-forming cyanobacteria like Aphanizomenon sp., Dolichospermum sp., or Microcystis sp. are often closely associated with other microorganisms, especially heterotrophic bacteria (Gerphagnon et al., 2015; Liu et al., 2014). It has been reported that these prokaryotes exchange substances (organic matter, energy, oxygen, nitrogen, phosphate) (Levy and Jami, 2018), which leads to a better growth of both partners. This would be a mutualistic partnership. However, some heterotrophic bacteria instead use cyanobacteria cells as a food source (Gerphagnon et al., 2015; Hoppe, 1981; Paerl and Otten, 2013; Yamamoto et al., 1998), and in aged Nodularia spumigena filaments an immense number of bacteria have been observed. However, there is so far little evidence for strong lysing effects of bacteria on cyanobacteria in natural environments.

\section{Viruses}

Viral lysis might have a much stronger impact for cyanobacteria than bacterial lysis. Viruses are ubiquitous in aquatic environments. Estimates assume that virus concentrations are more than $10^{7}-10^{10}$ viruses $\mathrm{mL}^{-1}$ (Rohwer and Youle, 2010; Paerl and Otten, 2013; Fuhrman and Suttle, 1993; S̆ulčius and Holmfeldt, 2016; Suttle, 2005; Breitbart, 2012; Zeigler Allen et al., 2017). In the Baltic Sea, Ahrens (1971) reports up to $3.7 \times 10^{4}$ viruses $\mathrm{mL}^{-1}$ for the bacteria group agrobacterium (which covers only a fraction of all bacteria). The more recent studies by Riemann et al. (2009) and Holmfeldt et al. (2010) estimate virus concentrations in a range from 3.0 to $4.9 \times 10^{7}$ viruses per $\mathrm{mL}^{-1}$. For reference, concentrations of viruses in air (outdoor) are around 0.26 viruses per $\mathrm{mL}^{-1}$ (Prussin et al., 2015).

Viruses are the most abundant biological entities in the ocean, and their numbers can exceed that of bacteria by about 5-10-fold (Silveira and Rohwer, 2016; Paerl and Otten, 2013). Most of these viruses are bacteriophages (a virus that infects and replicates within bacteria and archaea). Cyanophages are viruses that infect and replicate within a cyanobacteria. Viruses follow a similar distribution pattern to bacteria, with higher abundances in productive waters and lower abundances in oligotrophic regions (Bratbak et al., 1994; Fuhrman and Suttle, 1993). Also, viruses are much more abundant in freshwater than in marine systems (Maranger and Bird, 1995). In the Baltic Sea, virus-induced bacterial mortality is among the highest reported for temperate aquatic ecosystems (Weinbauer and Rassoulzadegan, 2003).

The importance of viruses in controlling cyanobacteria abundances is, however, still poorly understood. There is little evidence for the impact of viruses on cyanobacteria. A wide range of $20 \%-50 \%$ has been estimated for daily marine bacteria cell mortality due to viral lysis (Suttle, 2005; Fuhrman, 1999; Breitbart et al., 2007). Other studies indicate that viral-induced bacterial mortality might be an important factor, controlling bacterial, algal, and cyanobacterial abundances (Wommack and Colwell, 2000; Bratbak et al., 1993; Fuhrman and Suttle, 1993; Šulčius and Holmfeldt, 2016). This mortality is even suspected of exceeding the effect of zooplankton grazing, especially in nutrient-rich, brackish waters like the Baltic Sea (Paerl and Otten, 2013). In a mesocosm experiment in the Baltic Sea, Bratbak et al. (1992) estimate that viral lysis leads to a reduction of up to $72 \%$ of cyanobacterial cells per day. However, in Australia it was shown that cyanobacteria cells which survive a virus attack later develop a resistance against the virus (Tucker and Pollard, 2005). Still, Šulčius et al. (2015) could show in the Baltic Sea that the growth rate of Aphanizomenon flos-aquae was significantly suppressed by a virus infection. While lytic infections (a viral reproduction cycle which results in the destruction of the infected cell) do not play an important role when diversity of bacteria/cyanobacteria is high, a bloom of one specific host increases the risk of lytic infections drastically ("killing the winner hypothesis") (Bratbak et al., 1994). In enclosure experiments, Simis et al. (2005) could indeed observe the termination of cyanobacteria blooms due to virus pathogens.

In summary, ongoing research indicates that viruses could play a very important role in controlling cyanobacteria blooms (Weinbauer et al., 2003; Tucker and Pollard, 2005). Quantitative studies that assess the influence of viruses on cyanobacteria in the Baltic Sea, are, however, yet to come.

\section{Infections and lysis - antagonistic, indirect effects}

High cell turnover, due to virus lysis, has a large impact on daily nutrient recycling. Especially bacteria and flagellates benefit from the released nutrients from lysed cyanobacteria cells. Even cyanobacteria themselves are, most likely, able to recycle the nutrients from lysed cells (Breitbart, 2012; Bratbak et al., 1994; S̆ulčius and Holmfeldt, 2016; Hewson et al., 2004). Bratbak et al. (1992) could show in a mesocosm experiment that the whole bacterial and primary community could be sustained with organic phosphorus released from lysed cells. Especially in the Baltic Sea for Nodularia spumigena, with its low phosphorus requirements and high affinity for DOP (Degerholm et al., 2006), recycled phosphorus might be an important continuous nutrient source.

Another aspect of viruses is that viral lysis can shorten long filaments of cyanobacterial blooms. Šulčiu et al. (2017a) observed that viral lysis changed the filament morphology of a cyanobacteria colony substantially. During the experiment the mean filament length of the Baltic Sea species Aphanizomenon flos-aquae decreased by $58 \%$, which made the cyanobacteria more vulnerable to grazing by zooplankton. To protect against grazing and viral lysis cyanobacteria 
have been observed to produce an exopolysaccharide matrix that surrounds the colony-embedded filaments (ك̌ulčiu et al., 2017b).

\subsubsection{Grazing on cyanobacteria}

Several studies suggested that there is hardly any grazing on cyanobacteria due to their toxicity, bioactive compounds that hamper digestion, bad taste, poor content of lipids, large filamentous size, and low food quality (Carey et al., 2012; Daewel and Schrum, 2013; Ger et al., 2016). All considered models agree in that cyanobacteria are grazed less than other phytoplankton, while the precise proportions vary between the models (Table 4). Generally, prey morphology is thought to be one of the most important factors influencing zooplankton grazing (Gerphagnon et al., 2015). With their large, filamentous size, most bloom-forming cyanobacteria in the Baltic Sea are difficult to graze. The toxins produced by cyanobacteria are another obstacle for grazers, as these can be lethal. For example, microcystin is lethal for a wide range of daphnia and copepod species (DeMott and Moxter, 1991; Ger et al., 2019). Ciliates on the other end of the spectrum are most tolerant to microcystin.

Despite all these obstacles there is some grazing on cyanobacteria. One way is that grazers can develop a certain tolerance: especially during longer exposure to cyanobacteria, there can be a remarkably high biomass of small-bodied zooplankton which co-exist with cyanobacteria (Bouvy et al., 2001; Davis et al., 2012; Ger et al., 2016). This coexistence can lead to better-adapted grazer species (Davis et al., 2012; Bouvy et al., 2001; Sousa et al., 2008). DeMott and Moxter (1991) found that copepods and daphnias became more tolerant against toxins after exposure to toxic cyanobacteria - or better at avoiding them. This tolerance could even be transferred to their offspring (Gustafsson et al., 2005). Sarnelle (2007) observed that high abundances of generalists may even control cyanobacteria blooms if zooplanctivorous fish are rare. Carpenter (1989) proposed that cyanobacteria may be highly vulnerable to grazing at the time of initial recruitment. In this line, Chan $(2004,2006)$ could show that zooplankton can suppress cyanobacteria blooms.

In summary, grazing might be an important factor during the start of the growing phase and during termination of cyanobacteria blooms. Globally and specifically in the Baltic Sea, it can be observed that under favourable conditions, cyanobacteria can easily outgrow grazing pressure (Walve and Larsson, 2007; Ger et al., 2016; Sellner, 1997; Paerl and Otten, 2013). This rather low grazing pressure on cyanobacteria has a huge ecosystem impact, as, consequently, during cyanobacteria blooms a lower proportion of the primary production is consumed by larger grazers and is therefore not transferred to higher trophic levels. These findings are represented in the models by assuming that grazing on diatoms or other phytoplankton is 2-4 times higher than grazing on cyanobacteria. There is, however, no consensus yet on the ex- act formulation of zooplankton grazing in the current model generation, and grazers are represented by a single (BALTSEM, ERGOM, SCOBI, and CEMBS) or two (ECOSMO) functional groups.

In the Baltic Sea a wide range of possible grazers on cyanobacteria exist. To highlight the differences between different grazers, we discuss in the following the most abundant grazers (copepods, rotifers, and cladocerans) and some grazers, which are known to be able to exert a strong impact on cyanobacteria in other ecosystems (bivalves, protozoa). In each group we present their occurrence in the Baltic Sea, their feeding mode, and their grazing pressure on cyanobacteria.

\section{Copepods}

Among the most important and abundant grazers in the Baltic Sea are copepods. Typical species of copepods in the Baltic Sea are e.g. Acartia logiremis, Temora longicornis, or Centropages hamatus (Eglite et al., 2019; Wasmund et al., 2019). Copepods are a group of small crustaceans and belong to the mesozooplankton. They can select their food and can avoid cyanobacteria or select smaller colonies of cyanobacteria while grazing (Ger et al., 2019). One reason for their avoidance of cyanobacteria is the cyanobacterial toxins, which are lethal for many copepod species. Also, many filamentous cyanobacteria are too large to be grazed on. In accordance with this, most studies about copepod grazing on cyanobacteria in the Baltic Sea show no significant grazing effect on cyanobacteria (Sellner et al., 1994; Sellner and Olli, 1996; Engström, 2000; Sommer et al., 2006). On the contrary, copepod-dominated zooplankton communities may also facilitate cyanobacteria by preying selectively on the eukaryotic competitors (Ger et al., 2016; Hong et al., 2013). Similar results are found by Eglite et al. (2019), who could demonstrate based on fatty acids, amino acids, and stable carbon isotope analysis that mesozooplankton obtained essential fatty acids (FAs) and amino acids (AAs) from cyanobacteria via feeding on mixotrophic and heterotrophic (dino)flagellates and detrital complexes. Overall, while copepods play an important grazing role in the ecosystem, they are not able to control cyanobacteria growth in the Baltic Sea (Sommer et al., 2006).

\section{Cladocera}

The cladocera are another group of small crustaceans which typically range in size from 0.2 to $3.0 \mathrm{~mm}$. While most cladoceran species live in freshwater, eight species are truly oceanic. In the Baltic Sea the cladoceras Bosmina coregoni, Evadne nordmanni, and Daphnia cristata are very common, among others.

Cladocera are generalists, but there is a profound difference in the methods of food collection between littoral, planktonic, and predatory cladocera species (Smirnov, 
2017). Planktonic species are mostly filter feeders, but members of the family Bosmina are known to have a dual feeding mechanism. They have mesh-like structures for filtering, but they also can grab larger particles with their first two thorax limbs (Bleiwas and Stokes, 1985). By this, they are able to select for food items. In line with this, Kerfoot and Kirk (1991) demonstrate that two species of Bosmina spp. consume algal foods by size and taste. They show preferences for small algae, bacteria, and detritus (Solis et al., 2018). In contrast to this, filter-feeding cladoceras consume algae that are present in the water as well as organic particles and bacteria. Due to their feeding method, they are not able to avoid toxic cyanobacteria (Ger et al., 2019). Even so, Ismail et al. (2019) report that cladoceras species (here Daphniidae) were mostly feeding on small green algae cells. Filamentous cyanobacteria (Dolichospermum circinalis, Microcystis flos-aquae, and Dolichospermum sp.) were also utilized by the grazers, but to a minor degree. In contrast to this is that in freshwater lakes cladoceras are among the most important grazers on cyanobacteria. Especially the large-bodied Daphnia magna (max. female size $5 \mathrm{~mm}$ ) is capable of suppressing filamentous cyanobacteria (Urrutia-Cordero et al., 2016), whereas Daphnia cristata is one of the smallest daphnia (max. female size $1.6 \mathrm{~mm}$ ) and cannot exert high grazing pressure on filamentous cyanobacteria and Bosmina coregoni and Evadne nordmanni have a similar size (max. female size $1.5 \mathrm{~mm}$ ). In summary, in the Baltic Sea there is an abundant number of cladocerans, mostly smaller species. In contrast to freshwater habitats, studies suggest that cladocerans will not be able to suppress cyanobacteria blooms.

\section{Rotifera}

Another important grazing group are rotifers. Typical species in the Baltic Sea are among others Synchaeta baltica and Keratella quadrata. They are much smaller zooplankton species than copepods and belong to the size class micro-zooplankton. However, since the rotifers have higher metabolic rates and are considerably more abundant than crustaceans, they may be important in the structuring of plankton communities (Gilbert and Bogdan, 2017). Also, rotifers have the fastest reproductive rates of any metazoans (Mironova et al., 2008) and can reproduce unisexually or bisexually. Therefore, rotifers can quickly respond to altered food supply. In the brackish waters of the Baltic Sea rotifers are a highly diverse and widely distributed group. They are especially diverse and abundant (up to $95 \%$ of zooplankton biomass) in coastal ecosystems (Ojaveer, 2010). With increasing salinity, abundance and diversity of rotifers decrease due to the freshwater origin of this group. Furthermore, in the open Baltic Sea, rotifers are less diverse than in the Baltic Sea estuaries (Mironova et al., 2008). Most rotifers are suspension feeders. Due to their small size, their diet must be tiny as well. It mostly consists of dead or decomposing organic material as well as unicellular microalgae, bacteria, or protozoans (Mironova et al., 2008). Some species are known to be cannibalistic. Rotifers will not graze on living filamentous cyanobacteria, because they are too small. However, decaying cyanobacteria or smaller cyanobacteria like "Synechococcus" can be a target for rotifers.

\section{Bivalves}

In general bivalves are filter feeders. However, at least some mussel species can distinguish between food particles and show different clearance rates for different particle sizes or particle types. Another way mussels select food items is to reject particles by discarding them into pseudofeces (Ward et al., 2004; Tang et al., 2014). Ward et al. (2004) report that e.g. scallops showed lower clearance rates for toxic dinoflagellates than for three different plankton species. Regardless of the partial ability to select food particles, mussels are very successful grazers on cyanobacteria in freshwater lakes. For example, populations of Dreissena spp. were able to reduce cyanobacteria on several occasions (White and Sarnelle, 2014) and even prevented or terminated cyanobacteria blooms (Gulati et al., 2008; Baker et al., 1998). In the Baltic Sea, due to its brackish water, Dreissena polymorpha has become a part of the Baltic coastal ecosystem in many areas. While its distribution is patchy along the coast of the Baltic Sea (Werner et al., 2012), in the oligohaline southern and eastern coastal lagoons and inlets of the Baltic Sea Dreissena polymorpha is one of the most common species (Snoeijs-Leijonmalm et al., 2017) and could play a role in decreasing cyanobacteria blooms in coastal areas.

\section{Protozoa}

Protozoans, such as ciliates and flagellates, are an important group of grazers on cyanobacteria (Worden et al., 2015). Due to their small size they mainly consume unicellular cyanobacteria. Some ciliates and amoebae however can engulf prey items several times their own length by breaking down trichomes or encapsulating individual cells from cyanobacterial colonies (Ger et al., 2016). Dryden and Wright (1987) gave a great overview of grazing on cyanobacteria by different protozoa classes. The cited studies (mostly laboratory experiments) showed dinoflagellates, amoebae, and ciliates grazing on the order Nostocales, which comprises the cyanobacteria studied here. For example, Hoppe (1981) measures in the Baltic Sea that the ciliate Nocardia sp. become the dominant species in aged cyanobacteria filaments. Nocardia sp. can cause lysis of cyanobacteria (Hoppe, 1981). In lakes Canter et al. (1990) observed that the cyanobacteria population crashed under grazing pressure of the ciliate Nassula spp. Nassula spp. has the remarkable ability to ingest long filaments of cyanobacteria by sucking them in spaghetti-like and coiling them intracellularly (Reynolds, 2006). Similar results reported (Boyer et al., 2011) that while the microzooplankton (among others ciliates) community did 
not graze on filamentous cyanobacteria during the summer bloom, by autumn, as the cyanobacteria bloom was declining, microzooplankton grazing rates were high, particularly on Aphanizomenon flos-aquae. Cook (1974) report that the amoebae Mayorella were actively and exclusively grazing on Dolichospermum cells, reducing within $3 \mathrm{~d}$ the cyanobacteria bloom into a milk-like surface film. Also, Reynolds and Walsby (1975) observed a rapid collapse of a Dolichospermum circinalis bloom after being attacked by a large population of ciliates Ophryoglena atra.

These studies show that protozoans have the potential to exceed a strong grazing pressure on cyanobacteria. In the Baltic Sea the abovementioned species Mayorella sp., Ophryoglena sp., and Nassula sp. do occur. Their importance still has to be examined.

\subsection{Other factors}

\subsubsection{Salinity constraints}

The Baltic Sea features a wide range of salinities, ranging from 15 to 25 PSU in the north-western part of the Baltic to 2-3 PSU in the Bothnian Bay. The Baltic Proper, situated in the centre, is characterized by intermediate values around 68 PSU. The large spatial variance in salinity can induce large local salinity variations over time when ocean currents mix water masses from different origins. This can decrease the local growth and photosynthesis rates of algae and cyanobacteria once specific salinity thresholds are overcut or undercut and physiological stress sets in. By this mean salinity has the potential to control the occurrence of cyanobacteria species. Salinity thresholds are set in SCOBI and ECOSMO, where growth is not permitted above 10 and 11.5 PSU, respectively. The other models do not include salinity constraints on simulated cyanobacteria.

Field observations show that in most parts of the Baltic Sea large cyanobacteria blooms occur during summer, except in the relatively saline waters in the Kattegat and the Belt Sea. Thus e.g. Rakko and Seppäälä (2014) conclude, in line with the SCOBI and ECOSMO models, that high salinities seem to restrict the growth of Baltic Sea cyanobacteria and estimate a threshold around 10 PSU. Low salinities, in contrast, do not seem to restrict the growth of cyanobacteria in the Baltic Sea in general, and several studies report blooms at very low values: Wasmund (1997) relates Baltic Sea blooms to salinities between 3.8 and 11.5 PSU and Kononen et al. (1996) report no significant correlation of the bloom-forming cyanobacteria in the Gulf of Finland with salinity (i.e. salinities between 3 and 6 PSU).

The differences between species are substantial. Brutemark et al. (2015) even state that salinity might be one of the main factors that explains the distribution of species in the Baltic Sea. These statements are supported by laboratory experiments which we list in the following for the most relevant species.
- Aphanizomenon flos-aquae is known as a freshwater species (Laamanen et al., 2002). Accordingly, Rakko and Seppäälä (2014) and Laamanen et al. (2002) measured rather low salinities of 0-5 PSU for optimal growth. Rakko and Seppäälä (2014) describe this species as rather coastal, preferring less saline conditions. In line with this, Lehtimäki et al. (1997) state that Aphanizomenon flos-aquae is not able to tolerate salinities higher than 10 PSU. Consequently, its abundance decreases from the northern to the southern part of the Baltic Proper.

- The taxa Dolichospermum originate from freshwater, with some strains adapted to brackish water (Brutemark et al., 2015). In agreement, in the Baltic Sea the species Dolichospermum flos-aquae shows similar growth rates between 0 and 10 PSU and a strong decrease in growth rates at higher salinities (Moisander et al., 2002).

- For different strains of Nodularia spumigena a wide range of tolerable salinities were reported, 0-20 PSU (Moisander et al., 2002; Lehtimäki et al., 1997), while Rakko and Seppäälä (2014) and Nordin et al. (1980) narrow the optimal salinity range down to 5-10 PSU.

To sum up, in most areas of the Baltic Sea, salinity is no restriction for growth of cyanobacteria (an exception is the Danish Straits). Interestingly, however, salinities apparently affect the toxicity of cyanobacteria blooms: MazurMarzec et al. (2005) report an increase in Nodularin production for Nodularia spumigena with increasing salinity concentrations. In line with this, Brutemark et al. (2015) found the highest intracellular toxin concentration at the highest tested salinity concentrations (6 PSU) for Dolichospermum spp.

\subsubsection{Cyanobacteria akinetes}

The considered biogeochemical models do not consider the life cycle of cyanobacteria (e.g. the resting spores akinetes). A respective approach, was, however, tested successfully in a low-dimensional setup by Hense (2007) and Hense and Beckmann (2010). In the Baltic, all dominant bloom-forming diazotroph cyanobacteria taxa are able to produce akinetes. These resting spores have a slightly thicker cell wall than vegetative cells and are more resistant to environmental stress (e.g. temperature, desiccation) (Agrawal, 2009; Paerl, 2014; Kaplan-Levy et al., 2010). Some akinetes will germinate shortly after formation or after a more or less longer maturation period. For example, akinetes of Dolichospermum sp. were able to germinate even after a dormant phase of 64 years (Kaplan-Levy et al., 2010). Laboratory experiments indicate that akinetes need a certain time to mature and to reach a certain energy or nutrient level before germination is initiated again (Hense and Beckmann, 2006; Kaplan-Levy et al., 2010). The dormant akinetes can act as an overwinter- 
ing stadium or they can ensure the long-term survival of the population. Different stimuli like temperature, light intensity, a low DIN/DIP ratio, sediment resuspension, and salinity can trigger germination of akinetes (Karlsson-Elfgren et al., 2004; Rengefors et al., 2004; Kaplan-Levy et al., 2010; Huber, 1985; Sommer et al., 2006).

Field observations and mesocosm experiments indicate that the importance of akinetes for the main bloom-forming cyanobacteria taxa in the Baltic Sea differs from species to species (Sellner, 1997; Agrawal, 2009; Rother and Fay, 1977; Suikkanen et al., 2010). For example,

- Aphanizomenon flos-aquae seems to have a holoplanktonic life strategy (Rother and Fay, 1977; Jones, 1979; Head et al., 1999; Wasmund, 2017). It can produce akinetes, but during winter a "refuge population" of filaments can be observed in deeper waters (Heiskanen and Olli, 1996) even under sea ice (Laamanen et al., 2002), from which in spring/early summer the population will develop (Sellner, 1997; Suikkanen et al., 2010).

- Observations for Dolichospermum spp. are not conclusive: in the Baltic Sea, akinete formation of Dolichospermum spp. has been documented (Olli et al., 2005). However, Rother and Fay (1977) observed that the bulk of akinetes of Dolichospermum spp. germinated shortly after sporulation and that the overwintering population consisted of vegetative filaments, while Suikkanen et al. (2010) stated that Dolichospermum spp. regularly germinated from overwintering akinetes in the sediment. Cirés et al. (2013) found a dual strategy for Dolichospermum spp., with major akinete production combined with pelagic overwintering filaments. Dolichospermum spp. is the least dominant taxa of these three main bloom-forming Nostocales in the Baltic Sea.

- The other major bloom-forming taxa in the Baltic Sea - Nodularia spumigena - seems to have a mixed life strategy. It produces akinetes that overwinter in shallow sediments (Jones et al., 1994), but Nodularia spumigena only germinated from akinetes occasionally and mainly uses trichomes that overwinter in the water column (Suikkanen et al., 2010). In tank experiments Nodularia spumigena only grew within water from above the halocline, without additional input from akinetes (Wasmund, 2017).

In summary, the effect of akinetes on the extent of subsequent blooms is still under discussion and difficult to estimate. Based on field observations and literature data, KaplanLevy et al. (2010) draw the conclusion that the contribution of akinetes towards the bloom success of next year's population of Nostocales seems to be rather small. Cirés et al. (2013) suggest that the growth rate of the initial population has a bigger impact on bloom formation than the size of the inoculum (Rücker et al., 2009). Therefore, Kanoshina et al.
(2003) assume that beneficial environmental conditions at the start of the growing season are the major factors in the development of extensive cyanobacteria blooms.

\section{Discussion}

In the foregoing sections, we provided an overview of the current knowledge about Baltic Sea cyanobacteria from the perspective of both modellers and biologists. In the following we discuss key differences between model approaches and observational evidence (Sect. 4.1). Section 4.2 debates the impact of the oceanic processes on the Baltic Sea. Some considerations about model assessment metrics are in Sect. 4.3. In Sect. 4.4 we elaborate the potential impact of the model differences on projections and suggest future work directions.

\subsection{Biogeochemical processes}

We compared five state-of-the-art biogeochemical models, utilized for political decision-making regarding their underlaying assumptions for simulating cyanobacteria abundance. Our elaborations illustrate that, to date, there is only limited consensus on the degree of simplification and concerning key processes necessary for a reliable simulation cyanobacteria distribution and biomass. There is a certain agreement between modellers to focus only on one cyanobacteria class whose growth is generally controlled by the availability of light and phosphate. All model parameters associated with this single class of cyanobacteria are necessarily a compromise of the very different observed values for different species (cf. Tables 5, 7, and 8). This compromise is typically reached by adjusting the model parameters within their known bounds until the simulated cyanobacteria show a reasonable agreement with observations (cf. Löptien and Dietze, 2015; Schartau et al., 2017). The respective parameter choices differ substantially from one model to another, depending on the focus of the respective modeller (Tables 3 and 4; Figs. 1 and 2). To this end we regard particularly the various choices of growth-permitting phosphate thresholds as critical, because we suspect that these parameter values might have a drastic effect on model-based investigations of future projections and nutrient load scenarios (cf. Löptien and Dietze, 2020). Another potentially problematic assumption which might introduce substantial uncertainty into model-based projections of nutrient load scenarios is the fixed Redfield ratio ingrained in most models and which does not account for the storage capacity of DIP by cyanobacteria. This might spuriously shrink their ecological niche. A related aspect, potentially introducing uncertainty, is the differentiation between dissolved inorganic (DIP) and dissolved organic phosphorus (DOP), which is currently not considered in the models. The ability of cyanobacteria to use DOP might increase their success under otherwise nutrient-replete con- 
ditions. We regard these effects as potentially important for nutrient-reduction scenarios.

For projections into our warming future we suspect that especially the very different temperature dependencies might introduce substantial uncertainty in the model responses. The largest uncertainties in model formulations are, however, related to processes that terminate blooms and require further research. To this end we want to highlight viruses that have been shown to be potentially very important but understudied agents in the system.

\subsection{Abiotic oceanic processes}

The occurrence of cyanobacteria is controlled by several abiotic factors, such as nutrient availability, light, temperature, salinity, mixed-layer depth, currents, and upwelling. This control is both direct and indirect. For example, temperature directly affects the speed of enzymatic reactions and as such photosynthesis rates and respiration. Temperature will also directly affect organisms by changing the oxygen concentration in seawater and its viscosity. Indirect controls include feedback loops where temperature changes the interactions and competition in the feedback (e.g. by promoting competitors or predators). Similar effects exist for surface mixedlayer dynamics, which modulates the average light levels experienced by phytoplankton cells dispersed in the surface layer. A deepening may e.g. promote buoyant species which manage to stay at the sunlit surface, while competitors and grazers are mixed downwards into dark ocean layers. Further complexity comes from abiotic nutrient transport which is determined by mixing processes and advection.

Given the prominent controls of abiotic processes on pelagic ecosystem dynamics it is desirable to ensure utmost realism in reproducing abiotic drivers. CEMBS, ECOSMO, ERGOM, and SCOBI attempt this by coupling to full general ocean circulation models (GCMs) which explicitly calculate three-dimensional current fields in response to wind and buoyancy fluxes prescribed at the surface. The underlying GCMs (POP, HAMSOM, MOM, and RCO, respectively) are conceptually very similar. In terms of spatial resolution, however, they span a wide range ( 1 to $5 \mathrm{~nm}$ horizontally and 2 to $5 \mathrm{~m}$ vertically). This suggests that their capability of reproducing small-scale processes such as local upwelling events will also span a wide range because those models incapable of explicitly resolving the flow fields, need to parameterize their effect by mixing coefficients. The choice of choosing the appropriate coefficient is, however, very important and very difficult (e.g. Burchard et al., 2005).

Differences between the underlying ocean models can be expected to impact the simulation of cyanobacteria, besides the biogeochemical processes Reissmann et al. (cf. also 2009): for example, the diazotrophic species Aphanizomenon sp. is able to utilize the upwelled DIP, despite relative cold temperatures in the upwelled waters (Nausch et al., 2009; Lips and Lips, 2008). Therefore, as upwelling events will af- fect the abundance of cyanobacteria, a correct representation in the underlying ocean model is of particular importance. To capture the latter, the respective ocean models need i.a. a sufficient horizontal and vertical resolution and also reliable boundary conditions and the respective derivation of the surface fluxes are of major importance (e.g. Hofmeister et al., 2011; Meier et al., 2011c; Meier and Kauker , 2003; Schrum and Backhaus, 1999; Dietze and Löptien, 2016). Without a good representation of these factors in the underlying ocean model parameter adjustments in the biogeochemical component lead inevitably to reciprocal bias compensation, i.e. flaws of the ocean component are compensating by tuning the biogeochemical module to obtain a reasonable good agreement between model and observations. The problem with such an approach is that such a bias compensation is not necessarily robust under changing environmental conditions (Löptien and Dietze, 2019).

\subsection{Model assessment metrics}

Given the above considerations, the assessment of a model that is designed for sensitivity studies, future projections, and political decision-making cannot be limited to cyanobacteria alone. Rather, a meaningful model assessment needs, in addition, to take the controlling mechanisms into account (such as the representation of nutrients, light, mixing, and upwelling). So far, however, no common model evaluation criteria exist. A major difficulty in this respect is limited data availability. It is already challenging to obtain large-scale observations of cyanobacteria, let alone all other abovementioned data (e.g. light conditions, nutrient distributions, zooplankton concentration, and virus abundances). Today, satellite data are, due to their easy accessibility, often the first choice. While it is well known that these data contain a considerable degree of uncertainty (e.g. Reinart and Kutser, 2006), it is the only data source to assess large-scale patterns of cyanobacteria and to evaluate simulated cyanobacteria blooms Baltic-wide. Thus, several studies compare the simulated distribution of cyanobacteria with satellite images. However, so far, these evaluations have mostly been limited to long-term averages or interannual variations of the maximum or cumulative surface area covered by cyanobacteria in the Baltic Proper (e.g. Eilola et al., 2011; Janssen et al., 2004). On a positive note, the amount of available in situ data increases continuously (e.g. by Ferry boxes: Kaitala et al., 2014; Łysiak-Pastuszak et al., 2012; Mazur-Marzec et al., 2013; Petersen et al., 2018; Lips and Lips, 2017). Thus, new model approaches are upcoming, including fuzzy (e.g. Lilover and Laanemets, 2006; Laanemets et al., 2006) and/or statistical models (e.g. Håkanson, 2009). Given the present situation of limited data availability, however, such promising approaches are still inconclusive. We expect that the open data policy of many institutes and public available data collections (like ICES or HELCOM) facilitate the development of more reliable models. 


\subsection{Future perspectives}

There is concern that cyanobacteria will benefit from climate change in decades to come (Karlberg and Wulff, 2013; Paerl and Otten, 2013; Visser et al., 2016). This concern is based e.g. on the fact that the growth and the nitrogen fixation of cyanobacteria are generally favoured by high temperatures (cf. Sect. 3.1.2). Further, the increased stratification and the lowered viscosity of seawater due to higher temperatures might favour buoyant species, such as Nodularia spumigena and Aphanizomenon flos-aquae.

Accordingly, a number of numerical models project a significant increase in cyanobacteria blooms in the future for the Baltic Sea (Hense et al., 2013; Neumann, 2010; Saraiva et al., 2019; Meier et al., 2012, 2019). In terms of actual numbers, however, the models diverge substantially. For example, the multi-model ensemble by Meier et al. (2012) projects a significant (but not specified) increase in cyanobacteria blooms, while the RCO-SCOBI-model projection of Meier et al. (2019) projects an increase in cyanobacteria blooms by $50 \%$ or the complete loss of cyanobacteria blooms, depending on the respective nutrient load scenario. Sensitivity experiments of the CLC model by Hense et al. (2013) estimate a future increase in cyanobacteria biomass of 2.3 -fold, while the ESCOM model of Neumann (2010) projects an earlier start of cyanobacteria blooms but lower concentrations. It is also not clear whether an increase in cyanobacteria biomass is also associated with an increase in nitrogen fixation. To this end numerical models give contradicting results: the multimodel ensemble by Saraiva et al. (2019) projects an increase in nitrogen fixation between $22 \%$ and $56 \%$ or a decrease down to $0 \%$, depending on the nutrient load and climate scenario. Hense et al. (2013), on the other hand, estimate that nitrogen fixation will be twice as high in future, while Neumann (2010) project similar mean nitrogen fixation rates to today rates.

The large spread between models is a challenge for stakeholders because it provides little guidance on the question of how management actions to limit eutrophication in the Baltic Sea affect nitrogen fixation. The latter is especially of concern because the nitrogen input by cyanobacteria might be of the same order of magnitude as the scheduled nutrient reduction by the Baltic Sea Action Plan (BSAP): a reduction of nitrogen loads of 601.720 t (Helcom, 2007) is put up against an estimated annual nitrogen input of $434.000-792.000 \mathrm{t}$ by cyanobacteria (Wasmund et al., 2005).

We rate specifically the unclear relationship between excess $\mathrm{P}$ and cyanobacteria growth and the relation between bloom intensity and nitrogen fixation as key for studies to come. The respective uncertainties, reported for the Baltic Sea, are consistent with findings by Löptien and Dietze (2020), who illustrate in a global model that future projections of diazotrophs may diverge considerably - depending on the specific model formulations that determine their ecological niche. We propose to extend related sensitivity studies to rate which model formulations are most impactful on future projections. It might well be the case that widely differing model formulations yield very similar (or very different) projections.

The ultimate goal is to determine the minimum number of processes that need to be explicitly resolved in order to ensure predictive skill. For this purpose we rate variance-based sensitivity analysis techniques (e.g. Sobol, 2001) as promising systematic approach. The major challenge in this respect is to keep the computational costs at bay. The use of surrogates (e.g. Preuss and von Toussaint, 2017) or spatially limited setups, can make such approaches computationally feasible. Another line of attack is the combination of laboratory, microcosm or field experiments with process-based mechanistic models. If, by clever design, the experimental work can quantify the effects of species traits and the interactions between species, then these information can be implemented in process-based mechanistic models; which again can be tested against additional sets of control experiments. By this mean, such mechanistic models may provide robust nuclei on which more complex models may be built. In any case, and as being essential to all approaches, we advocate increased efforts to gather additional observational data. Respective observations are key to assess the predictive skill of traditional numerical models and/or to continue with statistical models based on e.g. machine-learning techniques. Finally, we feel that in order to proceed in a cost-efficient manner, the modelling community must develop methods that allow for answering the question what kind of observations are actually needed to constrain their models - a task that is closely related to the development of model assessment metrics (cf. Sect. 4.3).

\section{Conclusions}

Our review summarizes current knowledge about cyanobacteria in the Baltic Sea from the peer-reviewed literature. We take both a "modeller's" and a "biologist's" perspective. We report that there is consensus between the five dissected biogeochemical models and biologists in that cyanobacteria have an advantage over other functional groups under nitrate-depleted conditions. Further, there is consensus that the growth of cyanobacteria can be controlled by the availability of light and phosphate. Other than that, the specific formulations of the underlying assumptions diverge (cf. Tables 3 and 4 and Figs. 1 and 2).

The reasons for the large differences between specific model formulations is that there are still considerable knowledge gaps: processes such as the utilization (capabilities) of DOP and the stoichiometric elasticity (i.e. the potential to deviate from the Redfield ratio) along with the impact of viruses, programmed cell death, and grazing are not comprehensively understood. Naturally, this translates into differing numerical representations of growth and decay of cyanobacteria assemblages. Further spread in the underlying assump- 
tions is introduced by the, necessarily, reductionist approach of modellers, which often contrasts with the more complex findings of ecologists - a problem especially prominent because the most dominant cyanobacteria species of the Baltic Sea are diverse and feature very differing traits (cf. Sect. 4.4 Future perspectives). To this end, the overarching question is how much complexity is needed for reliable projections.

In order to proceed, we advertise the use of variance-based sensitivity analyses (such as Sobol's method, Sobol, 2001) to determine the key parameters and processes from complex models - and to identify observations and suitable experimental designs for biological studies that may help to constrain these very parameters. By this and similar approaches we expect to make better use of the ever-increasing number of observations that are driven by a combination of persistence using established methods (such as satellite observations, (Bracher et al., 2009; Hansson and Hakansson, 2007; Kahru et al., 2020) and innovation (such as proxy-based hindcasts, Kaiser et al., 2020). In summary, we are confident that the reliability of projections of cyanobacteria dynamics will improve along with the development of suitable modeldata misfit metrics.

Author contributions. All the authors contributed to the content and structuring of the paper. The lead was taken by BM.

Competing interests. The authors declare that they have no conflict of interest.

Acknowledgements. Special thanks also to Ulrich Sommer, who always supported us with his advice. The authors extend their thanks to Ute Daewel and Justus van Beusekom, who reviewed the paper and made very constructive and helpful suggestions. A public comment made by Oleg Savchuk is also very much appreciated.

Financial support. Britta Munkes has been supported by the German Research Foundation ("Towards a deeper Understanding of Cyanobacteria Blooms in the Baltic Sea"; grant no. LO 1377/3-1). Heiner Dietze and Ulrike Löptien have been supported by the Helmholtz Association of German Research Centres (HGF) as part of the project "Reduced Complexity Models" (grant no. ZT-I-10).

The article processing charges for this open-access publication were covered by a Research Centre of the Helmholtz Association.

Review statement. This paper was edited by Perran Cook and reviewed by Ute Daewel and Justus van Beusekom.

\section{References}

Adam, B., Klawonn, I., Sveden, J. B., Bergkvist, J., Nahar, N., Walve, J., Littmann, S., Whitehouse, M. J., Lavik, G., Kuypers, M. M., and Ploug, H.: $\mathrm{N}_{2}$-fixation, ammonium release and $\mathrm{N}$-transfer to the microbial and classical food web within a plankton community, ISME J., 10, 450-459, https://doi.org/10.1038/ismej.2015.126, 2016.

Adam, D.: Variabilität der Auftriebsgeschwindigkeit filamentöser Cyanobakterien in der Ostsee, Master, Institut für Meereskunde, Christian-Albrecht-Universität, Kiel, Germany, 1999.

Agrawal, S. C.: Factors affecting spore germination in algae - review, Folia Microbiol., 54, 273-302, https://doi.org/10.1007/s12223-009-0047-0, 2009.

Ahrens, R.: Untersuchungen zur Verbreitung von Phagern der Gattung Agrobacterium in der Ostsee, Institut für Meereskunde, Universität Kiel, Germany, 102-112, 1971.

Almroth-Rosell, E., Eilola, K., Hordoir, R., Meier, H. E. M., and Hall, P. O. J.: Transport of fresh and resuspended particulate organic material in the Baltic Sea? A model study, J. Marine Syst., 87, 1-12, https://doi.org/10.1016/j.jmarsys.2011.02.005, 2011.

Ameisen, J. C.: The Origin of Programmed Cell Death, Science, 272, 1278-1279, https://doi.org/10.1126/science.272.5266.1278, 1996.

Andersson, A., Höglander, H., Karlsson, C., and Huseby, S.: Key role of phosphorus and nitrogen in regulating cyanobacterial community composition in the northern Baltic Sea, Estuar. Coast. Shelf S., 164, 161-171, https://doi.org/10.1016/j.ecss.2015.07.013, 2015a.

Andersson, A., Meier, H. E. M., Ripszam, M., Rowe, O., Wikner, J., Haglund, P., Eilola, K., Legrand, C., Figueroa, D., Paczkowska, J., Lindehoff, E., Tysklind, M., and Elmgren, R.: Projected future climate change and Baltic Sea ecosystem management, AMBIO, 44, 345-356, https://doi.org/10.1007/s13280-015-0654-8, 2015b.

Baker, S. M., Levinton, J. S., Kurdziel, J. P., and Shumway, S. E.: Selective feeding and biodeposition by Zebra mussels and their relation to changes in phytoplankton composition and seston load, J. Shellfish Res., 17, 1207-1213, 1998.

Berman-Frank, I., Bidle, K. D., Haramaty, L., and Falkowski, P. G.: The demise of the marine cyanobacterium, Trichodesmium spp., via an autocatalyzed cell death pathway, Limnol. Oceanogr., 49, 997-1005, https://doi.org/10.4319/lo.2004.49.4.0997, 2004.

Bleiwas, A. H. and Stokes, P. M.: Collection of large and small food particles by Bosmina, Limnol. Oceanogr., 30, 1090-1092, https://doi.org/10.4319/lo.1985.30.5.1090, 1985.

Bouvy, M., Pagano, M., and Trousellier, M.: Effects of a cyanobacterial bloom (Cylindrospermopsis raciborskii) on bacteria and zooplankton communities in Ingazeira reservoir (northeast Brazil), Aquat. Microb. Ecol., 25, 215-227, https://doi.org/10.3354/ame025215, 2001.

Boyer, J., Rollwagen-Bollens, G., and Bollens, S. M.: Microzooplankton grazing before, during and after a cyanobacterial bloom in Vancouver Lake, Washington, USA, Aquat. Microb. Ecol., 64, 163-174, https://doi.org/10.3354/ame01514, 2011.

Bracher, A., Vountas, M., Dinter, T., Burrows, J. P., Röttgers, R., and Peeken, I.: Quantitative observation of cyanobacteria and diatoms from space using PhytoDOAS on SCIAMACHY data, Biogeosciences, 6, 751-764, https://doi.org/10.5194/bg-6-7512009, 2009. 
Bratbak, G., Heldal, M., Thingstad, T. F., Riemann, B., and Haslund, O. H.: Incorporation of viruses into the budget of microbial C-transfer, a first approach, Mar. Ecol. Prog. Ser., 83, 273-280, 1992.

Bratbak, G., Egge, J. K., and Heldal, M.: Viral mortality of the marine algae Emiliania huxleyi (Haptophyceae) and termination of algal blooms, Mar. Ecol. Prog. Ser., 93, 39-48, https://doi.org/10.3354/meps093039, 1993.

Bratbak, G., Thingstad, F., and Heldal, M.: Viruses and the microbial loop, Microbial Ecol., 28, 209-221, https://doi.org/10.1007/bf00166811, 1994.

Breitbart, M.: Marine viruses: truth or dare, Annu. Rev. Mar. Sci., 4, 425-448, https://doi.org/10.1146/annurev-marine120709-142805, 2012.

Breitbart, M., Thompson, L. R., Suttle, C. A., and Sullivan, M. B.: Exploring the Vast Diversity of Marine Viruses, Oceanography, 20, 135-139, https://doi.org/10.5670/oceanog.2007.58, 2007.

Breitburg, D., Levin, L. A., Oschlies, A., Gregoire, M., Chavez, F. P., Conley, D. J., Garcon, V., Gilbert, D., Gutierrez, D., Isensee, K., Jacinto, G. S., Limburg, K. E., Montes, I., Naqvi, S. W. A., Pitcher, G. C., Rabalais, N. N., Roman, M. R., Rose, K. A., Seibel, B. A., Telszewski, M., Yasuhara, M., and Zhang, J.: Declining oxygen in the global ocean and coastal waters, Science, 359, eaam7240, https://doi.org/10.1126/science.aam7240, 2018.

Brookes, J. D. and Ganf, G. G.: Variations in the boyancy response of Microcystis aeruginosa to nitrogen, phosphorus and light, J. Plankton Res., 23, 1399-1411, https://doi.org/10.1093/plankt/23.12.1399, 2001.

Brookes, J. D., Ganf, G. G., and Oliver, R. L.: Heterogeneity of cyanobacterial gas-vesicle volume and metabolic activity, J. Plankton Res., 22, 1579-1589, https://doi.org/10.1093/plankt/22.8.1579, 2000.

Brutemark, A., Vandelannoote, A., Engström-Öst, J., and Suikkanen, S.: A Less Saline Baltic Sea Promotes Cyanobacterial Growth, Hampers Intracellular Microcystin Production, and Leads to Strain-Specific Differences in Allelopathy, PLoS One, 10, e0128904, https://doi.org/10.1371/journal.pone.0128904, 2015.

Bugajev, A. O. and Koreiviene, J.: Determining optimal growth conditions for the highest biomass microalgae species in Lithuaninan Part of the Curonian Lagoon for further cultivation, Int. J. Environ. Res., 9, 233-246, 2015.

Burchard, H., Craig, P. D., Gemmrich, J. R., van Haren, H., Mathieu, P. P., Meier, H. M., Nimmo Smith, W. A. M., Prandke, H., Rippeth, T. P., Skyllingstad, E. D., Smyth, W. D., Welsh, D. J. K., and Wijesekera, W.: Observational and numerical modeling methods for quantifying coastal ocean turbulence and mixing, Prog. Oceanogr., 76, 399-442, https://doi.org/10.1016/j.pocean.2007.09.005, 2008.

Butterwick, C., Heaney, S. I., and Talling, J. F.: Diversity in the influence of temperature on the growth rates of freshwater algae, and its ecological relevance, Freshwater Biol., 50, 291-300, https://doi.org/10.1111/j.1365-2427.2004.01317.x, 2005.

Canter, H. M., Heaney, S. I., and Lund, J. W. G.: The ecological significance of grazing on planktonic populations of cyanobacteria by the ciliate Nassula, New Phytol., 114, 247-263, https://doi.org/10.1111/j.1469-8137.1990.tb00397.x, 1990.

Carey, C. C., Ibelings, B. W., Hoffmann, E. P., Hamilton, D. P., and Brookes, J. D.: Eco-physiological adaptations that favour fresh- water cyanobacteria in a changing climate, Water Res., 46, 13941407, https://doi.org/10.1016/j.watres.2011.12.016, 2012.

Carpenter, S. R.: Temporal variance in lake communities: bluegreen algae and the trophic cascade, Landscape Ecol., 3, 175184, https://doi.org/10.1007/BF00131536, 1989.

Chan, F., Pace, M. L., Howarth, R. W., and Marino, R. M.: Bloom formation in heterocystic nitrogen-fixing cyanobacteria: The dependence on colony size and zooplankton grazing, Limnol. Oceanogr., 49, 2171-2178, https://doi.org/10.4319/lo.2004.49.6.2171, 2004.

Chan, F., Marino, R. M., Howarth, R. W., and Pace, M. L.: Ecological constraints on planktonic nitrogen fixation in saline estuaries, II. Grazing controls on cyanobacterial population dynamics, Mar. Ecol. Prog. Ser., 309, 41-53, https://doi.org/10.3354/meps309041, 2006.

Cirés, S. and Ballot, A.: A review of the phylogeny, ecology and toxin production of bloom-forming Aphanizomenon spp. and related species within the Nostocales (cyanobacteria), Harmful Algae, 54, 21-43, https://doi.org/10.1016/j.hal.2015.09.007, 2016.

Cirés, S., Wörmer, L., Agha, R., and Quesada, A.: Overwintering populations of Anabaena, Aphanizomenon and Microcystis as potential inocula for summer blooms, J. Plankton Res., 35, 1254 1266, https://doi.org/10.1093/plankt/fbt081, 2013.

Claessen, D., Rozen, D. E., Kuipers, O. P., Søgaard-Andersen, L., and van Wezel, G. P.: Bacterial solutions to multicellularity: a tale of biofilms, filaments and fruiting bodies, Nat. Rev. Microbiol., 12, 115-124, https://doi.org/10.1038/nrmicro3178, 2014.

Clark, L. L., Ingall, E. D., and Benner, R.: Marine phosphorus is selectively remineralized, Nature, 393, 426, https://doi.org/10.1038/30881, 1998.

Conley, D. J., Humborg, C., Rahm, L., Svchuk, O. P., and Wulff, F.: Hypoxia in the Baltic Sea and basin-scale changes in phosphorus biogeochemistry, Environ. Sci. Technol., 36, 5315-5320, 2002.

Cook, W. L., Ahearn, D. G., Reinhardt, D. J., and Reiber, R. J.: Blooms of an algophorous amoeba associated with anabaena in a fresh water lake, Water, Air, and Soil Pollution, 3, 71-80, https://doi.org/10.1007/BF00282728, 1974.

Cottingham, K. L., Ewing, H. A., Greer, M. L., Carey, C. C., and Weathers, K. C.: Cyanobacteria as biological drivers of lake nitrogen and phosphorus cycling, Ecosphere, 6, 1-19, https://doi.org/10.1890/ES14-00174.1, 2015.

Daewel, U. and Schrum, C.: Simulating long-term dynamics of the coupled North Sea and Baltic Sea ecosystem with ECOSMO II: Model description and validation, J. Marine Syst., 119-120, 3049, https://doi.org/10.1016/j.jmarsys.2013.03.008, 2013.

Daewel, U. and Schrum, C.: Low-frequency variability in North Sea and Baltic Sea identified through simulations with the 3-D coupled physical-biogeochemical model ECOSMO, Earth Syst. Dynam., 8, 801-815, https://doi.org/10.5194/esd-8-801-2017, 2017.

Davis, T. W., Koch, F., Marcoval, M. A., Wilhelm, S. W., and Gobler, C. J.: Mesozooplankton and microzooplankton grazing during cyanobacterial blooms in the western basin of Lake Erie, Harmful Algae, 15, 26-35, https://doi.org/10.1016/j.hal.2011.11.002, 2012.

Degerholm, J., Gundersen, K., Bergman, B., and Söderbäck, E.: Phosphorus-limited growth dynamics in two Baltic Sea cyanobacteria, Nodularia sp. and Aphanizomenon sp., FEMS Microbiol. Ecol., 58, 323-332, https://doi.org/10.1111/j.15746941.2006.00180.x, 2006. 
DeMott, W. R. and Moxter, F.: Foraging on cyanobacteria by copepods: responses to chemical defences and resource abundance, Ecology, 72, 1820-1834, https://doi.org/10.2307/1940981, 1991.

DeNobel, W. T., Matthijs, H. C. P., Von Elert, E., and Mur, L. R.: Comparison of the light-limited growth of the nitrogen-fixing cyanobacteria Anabaena and Aphanizomenon, New Phytol., 138, 579-587, https://doi.org/10.1046/j.14698137.1998.00155.x, 1998.

Deutsch, C., Sarmiento, J. L., Sigman, D. M., Gruber, N., and Dunne, J. P.: Spatial coupling of nitrogen inputs and losses in the ocean, Nature, 445, 163-167, https://doi.org/10.1038/nature05392, 2007.

Diaz, R. J. and Rosenberg, R.: Marine benthic hypoxia: a review of its ecological effects and the behavioural responses of benthic macrofauna, Oceanogr. Mar. Biol., 33, 245-303, 1995.

Diaz, R. J. and Rosenberg, R.: Spreading Dead Zones and Consequences for Marine Ecosystems, Science, 321, 926-929, https://doi.org/10.1126/science.1156401, 2008.

Dietze, H. and Löptien, U.: Effects of surface current-wind interaction in an eddy-rich general ocean circulation simulation of the Baltic Sea, Ocean Sci., 12, 977-986, https://doi.org/10.5194/os12-977-2016, 2016.

Dolman, A. M., Rucker, J., Pick, F. R., Fastner, J., Rohrlack, T., Mischke, U., and Wiedner, C.: Cyanobacteria and cyanotoxins: the influence of nitrogen versus phosphorus, PLoS One, 7, e38757, https://doi.org/10.1371/journal.pone.0038757, 2012.

Dryden, R. C. and Wright, S. J. L.: Predation of cyanobacteria by protozoa, Can. J. Microbiol., 33, 471-482, https://doi.org/10.1139/m87-080, 1987.

Dyhrman, S. T. and Ruttenberg, K. C.: Presence and regulation of alkaline phosphatase activity in eukaryotic phytoplankton from the coastal ocean: Implications for dissolved organic phosphorus remineralization, Limnol. Oceanogr., 51, 1381-1390, https://doi.org/10.4319/lo.2006.51.3.1381, 2006.

Dzierzbicka-Głowacka, L., Janecki, M., Nowicki, A., and Jakacki, J.: Activation of the operational ecohydrodynamic model (3D CEMBS) - the ecosystem module, Oceanologia, 55, 543-572, https://doi.org/10.5697/oc.55-3.543, 2013.

Eglite, E., Graeve, M., Dutz, J., Wodarg, D., Liskow, I., SchulzBull, D., and Loick-Wilde, N.: Metabolism and foraging strategies of mid-latitude mesozooplankton during cyanobacterial blooms as revealed by fatty acids, amino acids, and their stable carbon isotopes, Ecol. Evol., 9, 9916-9934, https://doi.org/10.1002/ece3.5533, 2019.

Eigemann, F., Schwartke, M., and Schuly-Vogt, H.: Niche separation of Baltic Sea cyanobacteria during bloom events by species interactions and autecological preferences, Harmful Algae, 72, 65-73, https://doi.org/10.1016/j.hal.2018.01.001, 2018.

Eilola, K., Meier, H. E. M., and Almroth, E.: On the dynamics of oxygen, phosphorus and cyanobacteria in the Baltic Sea; A model study, J. Marine Syst., 75, 163-184, https://doi.org/10.1016/j.jmarsys.2008.08.009, 2009.

Eilola, K., Gustafsson, B. G., Kuznetsov, I., Meier, H. E. M., Neumann, T., and Savchuk, O. P.: Evaluation of biogeochemical cycles in an ensemble of three state-of-the-art numerical models of the Baltic Sea, J. Marine Syst., 88, 267-284, https://doi.org/10.1016/j.jmarsys.2011.05.004, 2011.
Elmgren, R.: Understanding Human Impact on the Baltic Ecosystem: Changing Views in Recent Decades, AMBIO, 30, 222-231, https://doi.org/10.1579/0044-7447-30.4.222, 2001.

Elmgren, R. and Larsson, U.: Nitrogen and the Baltic Sea: managing nitrogen in relation to phosphorus, Sci. World J., 1, 371-377, https://doi.org/10.1100/tsw.2001.291, 2001.

Engström, J., Koski, M., Viitasalo, M., Reinikainen, M. R., Repka, S., and Sivonen, K.: Feeding interactions of the copepods Eurytemora affinis and Acartia bifilosa with the cyanobacteria Nodularia sp., J. Plankton Res., 22, 1403-1409, https://doi.org/10.1093/plankt/22.7.1403, 2000.

Eppley, R. W.: The growth and culture of diatoms, in: The biology of diatoms, edited by: Werner, D., Botanical Monographs, Blackwell Scientific Publications, Oxford, London, Edinburgh, Melbourne, 24-64, https://doi.org/10.4319/lo.1979.24.1.0200, 1977.

Foy, R. H.: The influence of surface to volume ratio on the growth rates of planktonic blue-green algae, Brit. Phycol. J., 15, 279289, https://doi.org/10.1080/00071618000650281, 1980.

Foy, R. H., Gibson, C. E., and Smith, R. V.: The influence of daylength, light intensity and temperature on the growth rates of planktonic blue-green algae, Brit. Phycol. J., 11, 151-163, https://doi.org/10.1080/00071617600650181, 1976.

Franklin, D. J.: Explaining the causes of cell death in cyanobacteria: what role for asymmetric division?, J. Plankton Res., 36, 11-17, https://doi.org/10.1093/plankt/fbt114, 2013.

Fuhrman, J. A.: Marine viruses and their biogeochemical and ecological effects, Nature, 399, 541-548, https://doi.org/10.1038/21119, 1999.

Fuhrman, J. A. and Suttle, C. A.: Viruses in Marine Planktonic Systems, Oceanography, 6, 51-63, https://doi.org/10.5670/oceanog.1993.14, 1993.

Fuhs, G. W., Demnmerle, S. D., Canelli, E., and Chen, M.: Characterization of phosphorus-limited plankton algae, in: Nutrients and eutrophication, Amer. Soc. Limnol. Oceanogr. Spec. Symp. 1., edited by: Hutchinson, G. E. and Likens, G. E., Limnol. Oceanogr., 17, 113-133, https://doi.org/10.4319/lo.1972.17.6.0965, 1972.

Ganf, G. G. and Oliver, R. L.: Vertical separation of light and available nutrients as a factor causing replacement of green algae by blue-green algae in the plankton of a stratified lake, J. Ecol., 70, 829-844, https://doi.org/10.2307/2260107, 1982.

Ger, K. A., Urrutia-Cordero, P., Frost, P. C., Hansson, L. A., Sarnelle, O., Wilson, A. E., and Lürling, M.: The interaction between cyanobacteria and zooplankton in a more eutrophic world, Harmful Algae, 54, 128-144, https://doi.org/10.1016/j.hal.2015.12.005, 2016.

Ger, K. A., Naus-Wiezer, S., De Meester, L., and Lürling, M.: Zooplankton grazing selectivity regulates herbivory and dominance of toxic phytoplankton over multiple prey generations, Limnol. Oceanogr., 64, 1214-1227, https://doi.org/10.1002/lno.11108, 2019.

Gerphagnon, M., Macarthur, D. J., Latour, D., Gachon, C. M. M., Van Ogtrop, F., Gleason, F. H., and Sime-Ngando, T.: Microbial players involved in the decline of filamentous and colonial cyanobacterial blooms with a focus on fungal parasitism, Environ. Microbiol., 17, 2573-2587, https://doi.org/10.1111/14622920.12860, 2015.

Gilbert, J. J., and Bogdan, K. G.: Rotifer Grazing: In situ studies on selectivity and rates, in: Trophic Interactions Within Aquatic 
Ecosystems edited by: Meyers, D. G., CRC Press, New York, 97-134, https://doi.org/10.4324/9780429269608, 2017.

Gobler, C. J., Burkholder, J. M., Davis, T. W., Harke, M. J., Johengen, T., Stow, C. A., and Van de Waal, D. B.: The dual role of nitrogen supply in controlling the growth and toxicity of cyanobacterial blooms, Harmful Algae, 54, 87-97, https://doi.org/10.1016/j.hal.2016.01.010, 2016.

Gotham, I. J. and Rhee, G.-Y.: Comparative kinetic studies of phosphate-limited growth and phosphate uptake in phytoplankton in continuous culture, J. Phycol., 17, 257-265, https://doi.org/10.1111/j.1529-8817.1981.tb00848.x, 1981.

Gulati, R. D., Dionisio Pires, L. M., and Van Donk, E.: Lake restoration studies: Failures, bottlenecks and prospects of new ecotechnological measures, Limnologica, 38, 233-247, https://doi.org/10.1016/j.limno.2008.05.008, 2008.

Gustafsson, E.: Modeled long-term development of hypoxic area and nutrient pools in the Baltic Proper, J. Marine Syst., 94, 120 134, https://doi.org/10.1016/j.jmarsys.2011.11.012, 2012.

Gustafsson, E., Savchuk, O. P., Gustafsson, B. G., and MüllerKarulis, B.: Key processes in the coupled carbon, nitrogen, and phosphorus cycling of the Baltic Sea, Biogeochemistry, 134, 301-317, https://doi.org/10.1007/s10533-017-0361-6, 2017.

Gustafsson, S., Rengefors, K., and Hansson, L.-A.: Increased consumer fitness following transfer of toxin tolerance to offspring via maternal effects, Ecology, 86, 2561-2567, https://doi.org/10.1890/04-1710, 2005.

Håkanson, L.: A general process-based mass-balance model for phosphorus/eutrophication as a tool to estimate historical reference values for key bioindicators, as exemplified using data for the Gulf of Riga, Ecol. Model., 220, 226-244, https://doi.org/10.1016/j.ecolmodel.2008.09.012, 2009.

Hannerz, F. and Destouni, G.: Spatial Characterization of the Baltic Sea Drainage Basin and Its Unmonitored Catchments, AMBIO, 35, 214-219, https://doi.org/10.1579/05-a-022r.1, 2006.

Hansson, M. and Hakansson, B.: The Baltic Algae Watch System - a remote sensing application for monitoring cyanobacterial blooms in the Baltic Sea, J. Appl. Remote Sens., 1, 011507, https://doi.org/10.1117/1.2834769, 2007.

Head, R. M., Jones, R. I., and Bailey-Watts A. E.: An assessment of the influence of recruitment from the sediment on the development of planktonic populations of cyanobacteria in a temperate mesotrophic lake, Freshwater Biol., 41, 759-769, https://doi.org/10.1046/j.1365-2427.1999.00421.x,1999.

Healey, F. P: Characteristics of phosphorus deficiency in Anabaena, J. Phycol., 9, 383-394, https://doi.org/10.1111/j.15298817.1973.tb04111.x, 1973.

Heiskanen, A.-S. and Olli, K.: Sedimentation and buoyancy of Aphanizomenon cf. flosaquae (Nostocales, Cyanophyta) in a nutrient-replete and nutrient-depleted coastal area of the Baltic Sea, Phycologia, 35, 94-101, https://doi.org/10.2216/100318884-35-6S-94.1, 1996.

HELCOM: Baltic Sea Action Plan - Eutrophication segment of the HELCOM Baltic Sea Action Plan, HELCOM Ministerial Meeting, Krakow, Poland, 1-41, 15 November 2007.

HELCOM: Eutrophication status of the Baltic Sea 2007-2011 - A concise thematic assessment, Baltic Sea Environment Proceedings, 1-41, 143, 2014.

HELCOM: Sources and pathways of nutrients to the Baltic Sea, Baltic Sea Environment Proceedings, 1-48, 2018.
HELCOM: State of the Baltic Sea - Second HELCOM holistic assessment 2011-2016, Baltic Sea Environment Proceedings, 1$155,2018$.

Hellweger, F. L., Fredrick, N. D., McCarthy, M. J., Gardner, W. S., Wilhelm, S. W., and Paerl, H. W.: Dynamic, mechanistic, molecular-level modeling of cyanobacteria: Anabaena and nitrogen interaction, Environ. Microbiol., 18, 2721-2731, https://doi.org/10.1111/1462-2920.13299, 2016.

Hense, I.: Regulative feedback mechanisms in cyanobacteria-driven systems: a model study, Mar. Ecol. Prog. Ser., 339, 41-47, https://doi.org/10.3354/meps339041, 2007.

Hense, I. and Beckmann, A.: Towards a model of cyanobacteria life cycle-effects of growing and resting stages on bloom formation of $\mathrm{N}_{2}$-fixing species, Ecol. Model., 195, 205-218, https://doi.org/10.1016/j.ecolmodel.2005.11.018, 2006.

Hense, I. and Beckmann, A.: The representation of cyanobacteria life cycle processes in aquatic ecosystem models, Ecol. Model., 221, 2330-2338, https://doi.org/10.1016/j.ecolmodel.2010.06.014, 2010.

Hense, I., Meier, H. E. M., and Sonntag, S.: Projected climate change impact on Baltic Sea cyanobacteria, Climatic Change, 119, 391-406, https://doi.org/10.1007/s10584-0130702-y, 2013.

Hewson, I., Govil, S. R., Capone, D. G., Carpenter, E. J., and Fuhrman, J. A.: Evidence of Trichodesmium viral lysis and potential significance for biogeochemical cyling in the oligotrophic ocean, Aquat. Microb. Ecol., 36, https://doi.org/10.3354/ame036001, 2004.

Hofmeister, R., Beckers, J. M., and Burchard, H.: Realistic modeling of the exceptional inflows into the central Baltic Sea in 2003 using terrain-following coordinates, Ocean Model., 39, 233-247, https://doi.org/10.1016/j.ocemod.2011.04.007, 2011.

Holm, N. P. and Armstrong, D. E.: Role of nutrient limitation and competition in controlling the populations of Asterionella formosa and Microcystis aeruginosa in semicontinuous culture, Limnol. Oceanogr., 26, 622-634, https://doi.org/10.4319/lo.1981.26.4.0622, 1981.

Holmfeldt, K., Titelman, J., and Riemann, L.: Virus production and lysate recycling in different sub-basins of the northern Baltic Sea, Microbial Ecol., 60, 572-580, https://doi.org/10.1007/s00248010-9668-8, 2010.

Hong, Y., Burford, M. A., Ralph, P. J., Udy, J. W., and Doblin, M. A.: The cyanobacterium Cylindrospermopsis raciborskii is facilitated by copepod selective grazing, Harmful Algae, 29, 14-21, https://doi.org/10.1016/j.hal.2013.07.003, 2013.

Hoogenhout, H. and Amesz, J.: Growth rates of photosynthetic microorganisms in laboratory cultures, Arch. Mikrobiol., 50, 10 25, https://doi.org/10.1007/bf00439783, 1965.

Hoppe, H.-G.: Blue-Green algae agglomeration in surface water: a microbiotope of high bacterial activity, Kieler Meeresforschungen - Sonderheft, G. Wüst, Kiel, 291-303, 1981.

Huber, A. L.: Factors affecting the germination of akinetes of Nodularia spumigena (Cyanobacteriaceae), Appl. Environ. Microb. 49, 73-78, https://doi.org/0099-2240/85/010073-06,1985.

Ibelings, B. W.: Changes in photosynthesis in response to combined irradiance and temperature stress in cyanobacterial surface waterblooms, J. Appl. Phycol., 32, 549-557, https://doi.org/10.1111/j.0022-3646.1996.00549.x, 1996. 
Ibelings, B., Mur, L., Kinsman, R., and Walsby, A.: Microcystis changes its buoyancy in response to the average irradiance in the surface mixed layer, Arch. Hydrobiol., 120, 385-401, 1991.

Ismail, A. H., Mills, S., and Recknagel, F.: Feeding evaluation of microcrustacea (Cladocera): responses to variations in cell volume of green and blue-green algae, Appl. Ecol. Env. Res., 17, 7715-7725, https://doi.org/10.15666/aeer/1704_77157725, 2019.

Janssen, F., Neumann, T., and Schmidt, M.: Inter-annual variability in cyanobacteria blooms in the Baltic Sea controlled by wintertime hydrographic conditions, Mar. Ecol. Prog. Ser., 275, 59-68, https://doi.org/10.3354/meps275059, 2004.

Jodlowska, S. and Latala, A.: Photoacclimation strategies in the toxic cyanobacterium Nodularia spumigena (Nostocales, Cyanobacteria), Phycologia, 49, 203-211, https://doi.org/10.2216/PH08-14.1, 2019.

Jones, G. J., Blackburn, S. I., and Parker, N. S.: A toxic bloom of Nodularia spumigena Mertens in Orielton Lagoon, Tasmania, Aust. J. Mar. Fresh. Res., 45, 787-800, 1994.

Jones, R. I.: Notes on the growth and sporulation of a natural population of Aphanizomenon flos-aquae, Hydrobiologia, 62, 55-58, https://doi.org/10.1007/BF00012562, 1979.

Kahru, M., Elmgren, R., Kaiser, J., Wasmund, N., and Savchuk, O.: Cyanobacterial blooms in the Baltic Sea: Correlations with environmental factors, Harmful Algae, 92, 101739, https://doi.org/10.1016/j.hal.2019.101739, 2020.

Kaiser, J., Wasmund, N., Kahru, M., Wittenborn, A. K., Hansen, R., Häusler, K., Moros, M., Schulz-Bull, D., and Arz, H. W.: Reconstructing $\mathrm{N}_{2}$-fixing cyanobacterial blooms in the Baltic Sea beyond observations using 6- and 7-methylheptadecane in sediments as specific biomarkers, Biogeosciences, 17, 2579-2591, https://doi.org/10.5194/bg-17-2579-2020, 2020.

Kaitala, S., Kettunen, J., and Seppälä, J.: Introduction to Special Issue: 5th ferrybox workshop - Celebrating 20 years of the Algaline, J. Marine Syst., 140, 1-3, https://doi.org/10.1016/j.jmarsys.2014.10.001, 2014.

Kanoshina, I., Lips, U., and Leppänen, J.-M.: The influence of weather conditions (temperature and wind) on cyanobacterial bloom development in the Gulf of Finland (Baltic Sea), Harmful Algae, 2, 29-41, https://doi.org/10.1016/s1568-9883(02)000859, 2003.

Kaplan-Levy, R. N., Hadas, O., Summers, M. L., Rücker, J., and Sukenik, A.: Akinetes: Dormant Cells of Cyanobacteria, in: Dormancy and Resistance in Harsh Environments, Topics in Current Genetics, edited by: Lubzens, E., Cerda, J., and Clark, M., Springer, Berlin, Heidelberg, Germany, 5-27, https://doi.org/10.1007/978-3-642-12422-8, 2010.

Karlberg, M. and Wulff, A.: Impact of temperature and species interaction on filamentous cyanobacteria may be more important than salinity and increased $p \mathrm{CO}_{2}$ levels, Mar. Biol., 160, 20632072, https://doi.org/10.1007/s00227-012-2078-3, 2013.

Karlsson, K. M., Kankaanpää, H., Huttunen, M., and Meriluoto, J.: First observation of microcystin-LR in pelagic cyanobacterial blooms in the northern Baltic Sea, Harmful Algae, 4, 163-166, https://doi.org/10.1016/j.hal.2004.02.002, 2005.

Karlsson-Elfgren, I., Rengefors, K., and Gustafsson, S.: Factors regulating recruitment from the sediment to the water column in the bloom-forming cyanobacterium Gloeotrichia echinulata,
Freshwater Biol., 49, 265-273, https://doi.org/10.1111/j.13652427.2004.01182.x, 2004.

Kerfoot, W. C. and Kirk, K. L.: Degree of taste discrimination among suspension-feeding cladocerans and copepods: Implications for detritivory and herbivory, Limnol. Oceanogr., 36, 1107 1123, https://doi.org/10.4319/lo.1991.36.6.1107, 1991.

Klemer, A. R., Feuillade, J., and Feuillade, M.: Cyanobacterial blooms: carbon and nitrogen limitation have opposite effects on the buoyancy of Oscillatoria, Science, 215, 1629-1631, https://doi.org/10.1126/science.215.4540.1629, 1982.

Kononen, K. and Leppänen, J.-M.: Patchiness, scales and controlling mechanisms of cyanobacterial blooms in the Baltic Sea: application of a multiscale research strategy, in: Monitoring algal blooms: new techniques for detecting large-scale environmental change, edited by: Kahru, M. and Brown, C. W., Landes Bioscience, Austin, Texas, USA, 63-84, 1997.

Kononen, K., Kuparinen, J., and Mäkelä, K.: Initiation of cyanobacterial blooms in a frontal region at the entrance to the Gulf of Finland, Baltic Sea, Limnol. Oceanogr., 41, 98-112, https://doi.org/10.4319/lo.1996.41.1.0098, 1996.

Konopka, A. and Brock, T. D.: Effect of Temperature on BlueGreen Algae (Cyanobacteria) in Lake Mendota, Appl. Environ. Microb., 36, 572-576, 1978.

Konopka, A., Kromkamp, J., and Mur, L. R.: Regulation of gas vesicle content and buoyancy in light-or phosphate-limited cultures of Aphanizomenon flos-aquae (Cyanophyta), J. Phycol., 23, 70 78, https://doi.org/10.1111/j.0022-3646.1987.00070.x, 1987.

Kozik, C., Young, E. B., Sandgren, C. D., and Berges, J. A.: Cell death in individual freshwater phytoplankton species: relationships with population dynamics and environmental factors, Eur. J. Phycol., 54, 369-379, https://doi.org/10.1080/09670262.2018.1563216, 2019.

Kremp, C., Seifert, T., Mohrholz, V., and Fennel, W.: The oxygen dynamics during Baltic inflow events in 2001 to 2003 and the effect of different meteorological forcing? A model study, J. Marine Syst., 67, 13-30, https://doi.org/10.1016/j.jmarsys.2006.08.002, 2007.

Kromkamp, J., Konopka, A., and Mur, L. R.: Buoyancy regulation in a strain of Aphanizomenon-flos-aquae (Cyanophyceae) - The importance of carbohydrate accumulation and gas vesicle collapse, Journal of general microbiology, 132, 2113-2121, 1986.

Kruk, C., Huszar, V. L. M., Peeters, E. T. H. M., Bonilla, S., Costa, L., Lürling, M., Reynolds, C. S., and Scheffer, M.: A morphological classification capturing functional variation in phytoplankton, Freshwater Biol., 55, 614-627, https://doi.org/10.1111/j.1365-2427.2009.02298.x, 2010.

Kuznetsov, I. and Neumann, T.: Simulation of carbon dynamics in the Baltic Sea with a 3D model, J. Marine Syst., 111-112, 167174, https://doi.org/10.1016/j.jmarsys.2012.10.011, 2013.

Kuznetsov, I., Neumann, T., and Burchard, H.: Model study on the ecosystem impact of a variable $\mathrm{C}: \mathrm{N}: \mathrm{P}$ ratio for cyanobacteria in the Baltic Proper, Ecol. Model., 219, 107-114, https://doi.org/10.1016/j.ecolmodel.2008.08.002, 2008.

Laamanen, M. J., Forsstrom, L., and Sivonen, K.: Diversity of Aphanizomenon flos-aquae (Cyanobacterium) Populations along a Baltic Sea Salinity Gradient, Appl. Environ. Microb., 68, 52965303, https://doi.org/10.1128/aem.68.11.5296-5303.2002, 2002.

Laanemets, J., Lilover, M. J., Raudsepp, U., Autio, R., Vahtera, E., Lips, I., and Lips, U.: A Fuzzy Logic Model to De- 
scribe the Cyanobacteria Nodularia spumigena Blooms in the Gulf of Finland, Baltic Sea, Hydrobiologia, 554, 31-45, https://doi.org/10.1007/s10750-005-1004-x, 2006.

Landolfi, A., Kähler, P., Koeve, W., and Oschlies, A.: Global Marine $\mathrm{N}_{2}$ Fixation Estimates: from Observations to Models, Front. Microbiol., 9, 2112, https://doi.org/10.3389/fmicb.2018.02112, 2018.

LaRoche, J. and Breitbarth, E.: Importance of the diazotrophs as a source of new nitrogen in the ocean, J. Sea Res., 53, 67-91, https://doi.org/10.1016/j.seares.2004.05.005, 2005.

Larsson, U., Hajdu, S., Walve, J., and Elmgren, R.: Baltic Sea nitrogen fixation estimated from the summer increase in upper mixed layer total nitrogen, Limnol. Oceanogr., 46, 811-820, https://doi.org/10.4319/lo.2001.46.4.0811, 2001.

Lee, D.-Y. and Rhee, G.-Y.: Kinetics of cell death in the cyanobacterium Anabaena flosaquae and the production of dissolved organic carbon, J. Phycol., 33, 991-998, https://doi.org/10.1111/j.0022-3646.1997.00991.x, 1997.

Lee, D.-Y. and Rhee, G.-Y.: Kinetics of growth and death in Anabaena flosaquae (Cyanobacteria) and light limitation and supersaturation, J. Phycol., 35, 700-709, https://doi.org/10.1046/j.1529-8817.1999.3540700.x, 1999.

Lehtimäki, J., Sivonen, K., Luukainen, R., and Niemela, S. I.: The effects of incubation time, temperature, light salinity, and phosphorus on growth and hepatotoxin production by Nodularia strains, Arch. Hydrobiol., 130, 269-282, 1994.

Lehtimäki, J., Moisander, P., Sivonen, K., and Kononen, K.: Growth, nitrogen fixation, and nodularin production by two Baltic Sea cyanobacteria, Appl. Environ. Microb., 63, 16471656, 1997.

Levy, B. and Jami, E.: Exploring the Prokaryotic Community Associated with the Rumen Ciliate Protozoa Population, Front. Microbiol., 9, 1-14, https://doi.org/10.3389/fmicb.2018.02526, 2018.

Lewis, W. M.: Surface/Volume Ratio: Implications for Phytoplankton Morphology, Science, 192, 885-887, https://doi.org/10.1126/science.192.4242.885, 1976.

Lilover, M. J. and Laanemets, J.: A simple tool for the early prediction of the cyanobacteria Nodularia spumigena bloom biomass in the Gulf of Finland, Oceanologia, 48, 213-229, 2006.

Lin, S., Litaker, R. W., and Sunda, W. G.: Phosphorus physiological ecology and molecular mechanisms in marine phytoplankton, J. Phycol., 52, 10-36, https://doi.org/10.1111/jpy.12365, 2016.

Lin, X., Zhang, H., Cui, Y., and Lin, S.: High sequence variability, diverse subcellular localizations, and ecological implications of alkaline phosphatase in dinoflagellates and other eukaryotic phytoplankton, Front. Microbiol., 3, 1-13, https://doi.org/10.3389/fmicb.2012.00235, 2012.

Lips, I. and Lips, U.: Abiotic factors influencing cyanobacterial bloom development in the Gulf of Finland (Baltic Sea), Hydrobiologia, 614, 133-140, https://doi.org/10.1007/s10750-008-94492, 2008.

Lips, I. and Lips, U.: The importance of Mesodinium rubrum at post-spring bloom nutrient and phytoplankton dynamics in the vertically stratified Baltic Sea, Front. Mar. Sci., 4, 407-416, https://doi.org/10.3389/fmars.2017.00407, 2017.

Liu, L., Yang, J., Lv, H., and Yu, Z.: Synchronous dynamics and correlations between bacteria and phytoplankton in a subtropical drinking water reservoir, FEMS Microbiol. Ecol., 90, 126-138, https://doi.org/10.1111/1574-6941.12378, 2014.

Löptien, U.: Steady states and sensitivities of commonly used pelagic ecosystem model components, Ecol. Model., 222, 13761386, https://doi.org/10.1016/j.ecolmodel.2011.02.005, 2011.

Löptien, U. and Dietze, H.: Constraining parameters in marine pelagic ecosystem models - is it actually feasible with typical observations of standing stocks?, Ocean Sci., 11, 573-590, https://doi.org/10.5194/os-11-573-2015, 2015.

Löptien, U. and Dietze, H.: Reciprocal bias compensation and ensuing uncertainties in model-based climate projections: pelagic biogeochemistry versus ocean mixing, Biogeosciences, 16, 1865-1881, https://doi.org/10.5194/bg-16-1865-2019, 2019.

Löptien, U. and Dietze, H.: Contrasting juxtaposition of two paradigms for diazotrophy in an Earth System Model of intermediate complexity, Biogeosciences Discuss. [preprint], https://doi.org/10.5194/bg-2020-96, 2020.

Lund, J. W. G.: Studies on Asterionella: I. The Origin and Nature of the Cells Producing Seasonal Maxima, J. Ecol., 37, 389-419, https://doi.org/10.2307/2256614, 1949.

Lund, J. W. G.: Werner, D. [Ed.] 1977, The biology of diatoms, Bot. Monogr., V. 13, University of California Press, Berkeley and New York. vii + 498 p., Limnol. Oceanogr., 24, https://doi.org/10.4319/lo.1979.24.1.0200, 1979.

Lürling, M., Eshetu, F., Faassen, E. J., Kosten, S., and Huszar, V. L. M.: Comparison of cyanobacterial and green algal growth rates at different temperatures, Freshwater Biol., 58, 552-559, https://doi.org/10.1111/j.1365-2427.2012.02866.x, 2013.

Łysiak-Pastuszak, E., Bartoszewicz, M., Bradtke, K., Darecki, M., Drgas, N., Kowalczuk, P., Kraśniewski, W., Krężel, A., Krzymiński, W., Lewandowski, Ł., Mazur-Marzec, H., Piliczewski, B., Sagan, S., Sutryk, K., and Witek, B.: A study of episodic events in the Baltic Sea - combined in situ and satellite observations, Oceanologia, 54, 121-141, https://doi.org/10.5697/oc.54-2.121, 2012.

Maranger, R. and Bird, D. F.: Viral abundance in aquatic systems: a comparison between marine and fresh waters, Mar. Ecol. Prog. Ser., 16161599, https://doi.org/10.3354, 1995.

Mazur-Marzec, H., Żeglińska, L., and Pliński, M.: The effect of salinity on the growth, toxin production, and morphology of Nodularia spumigena isolated from the Gulf of Gdańsk, southern Baltic Sea, J. Appl. Phycol., 17, 171-179, https://doi.org/10.1007/s10811-005-5767-1, 2005.

Mazur-Marzec, H., Sutryk, K., Kobos, J., Hebel, A., Hohlfeld, N., Błaszczyk, A., Toruńska, A., Kaczkowska, M. J., ŁysiakPastuszak, E., Kraśniewski, W., and Jasser, I.: Occurrence of cyanobacteria and cyanotoxin in the Southern Baltic Proper. Filamentous cyanobacteria versus single-celled picocyanobacteria, Hydrobiologia, 701, 235-252, https://doi.org/10.1007/s10750012-1278-7, 2013.

Meier, H. E. M. and Kauker, F.: Modeling decadal variability of the Baltic Sea: 2. Role of freshwater inflow and large-scale atmospheric circulation for salinity, J. Geophys. Res.-Oceans, 108, 3368, https://doi.org/10.1029/2003JC001799, 2003.

Meier, H. E. M., Andersson, H. C., Eilola, K., Gustafsson, B. G., Kuznetsov, I., Müller-Karulis, B., Neumann, T., and Savchuk, O. P.: Hypoxia in future climates: A model ensemble study for the Baltic Sea, Geophys. Res. Lett., 38, 1-6, https://doi.org/10.1029/2011gl049929, 2011a. 
Meier, H. E. M., Eilola, K., and Almroth-Rosell, E.: Climaterelated changes in marine ecosystems simulated with a three-dimensional coupled physical-biogeochemical model of the Baltic Sea, Clim. Res., 48, 31-55, https://doi.org/10.3354/cr00968, 2011b.

Meier, H. E. M., Höglund, A., Döscher, R., Andersson, H., Löptien, U., and Kjellström, E.: Quality assessment of atmospheric surface fields over the Baltic Sea from an ensemble of regional climate model simulations with respect to ocean dynamics, Oceanologia, 53, 193-227, https://doi.org/10.5697/oc.53-1TI.193, 2011c.

Meier, H. E. M., Müller-Karulis, B., Andersson, H. C., Dieterich, C., Eilola, K., Gustafsson, B. G., Hoglund, A., Hordoir, R., Kuznetsov, I., Neumann, T., Ranjbar, Z., Savchuk, O. P., and Schimanke, S.: Impact of climate change on ecological quality indicators and biogeochemical fluxes in the Baltic sea: a multi-model ensemble study, AMBIO, 41, 558-573, https://doi.org/10.1007/s13280-012-0320-3, 2012.

Meier, H. E. M., Andersson, H. C., Arheimer, B., Donnelly, C., Eilola, K., Gustafsson, B. G., Kotwicki, L., Neset, T. S., Niiranen, S., Piwowarczyk, J., Savchuk, O. P., Schenk, F., Weslawski, J. M., and Zorita, E.: Ensemble modeling of the Baltic Sea ecosystem to provide scenarios for management, AMBIO, 43, 37-48, https://doi.org/10.1007/s13280-013-0475-6, 2014.

Meier, H. E. M., Dieterich, C., Eilola, K., Gröger, M., Höglund, A., Radtke, H., Saraiva, S., and Wählström, I.: Future projections of record-breaking sea surface temperature and cyanobacteria bloom events in the Baltic Sea, AMBIO, 48, 1362-1376, https://doi.org/10.1007/s13280-019-01235-5, 2019.

Mironova, E. I., Telesh, I. V., and Skarlato, S. O.: "Biodiversity of microzooplankton (ciliates and rotifers) in the Baltic Sea", in: IEEE/OES US/EU-Baltic International Symposium, Tallinn, Estonia, 27-29 May 2008, 1-5, https://doi.org/10.1109/BALTIC.2008.4625505, 2008.

Mohamed, Z. A., Hashem, M., and Alamri, S. A.: Growth inhibition of the cyanobacterium Microcystis aeruginosa and degradation of its microcystin toxins by the fungus Trichoderma citrinoviride, Toxicon, 86, 51-58, https://doi.org/10.1016/j.toxicon.2014.05.008, 2014.

Moisander, P. H., McClinton, E., and Paerl, H. W.: Salinity effects on growth, photosynthetic parameters, and nitrogenase activity in estuarine planktonic cyanobacteria, Microb. Ecol., 43, 432-442, https://doi.org/10.1007/s00248-001-1044-2, 2002.

Moisander, P. H., Paerl, H. W., Dyble, J., and Sivonen, K.: Phosphorus limitation and diel control of nitrogen-fixing cyanobacteria in the Baltic Sea, Mar. Ecol. Prog. Ser., 345, 41-50, https://doi.org/10.3354/meps06964, 2007.

Molot, L. A., Watson, S. B., Creed, I. F., Trick, C. G., McCabe, S. K., Verschoor, M. J., Sorichetti, R. J., Powe, C., Venkiteswaran, J. J., and Schiff, S. L.: A novel model for cyanobacteria bloom formation: the critical role of anoxia and ferrous iron, Freshwater Biol., 59, 1323-1340, https://doi.org/10.1111/fwb.12334, 2014.

Munn, C.: Ecology \& Applications, in: Marine Microbiology, 2 edn., Garland Science, New York, 1-364, https://doi.org/10.1201/9781136667527, 2011.

Nalewajko, C. and Murphy, T. P.: Effects of temperature, and availability of nitrogen and phosphorus on the abundance of Anabaena and Microcystis in Lake Biwa,
Japan: an experimental approach, Limnology, 2, 45-48, https://doi.org/10.1007/s102010170015, 2001.

Nausch, M., Nausch, G., Wasmund, N., and Nagel, K.: Phosphorus pool variations and their relation to cyanobacteria development in the Baltic Sea: A three-year study, J. Marine Syst., 71, 99111, https://doi.org/10.1016/j.jmarsys.2007.06.004, 2008.

Nausch, M., Nausch, G., Lass, H. U., Mohrholz, V., Nagel, K., Siegel, H., and Wasmund, N.: Phosphorus input by upwelling in the eastern Gotland Basin (Baltic Sea in summer and its effects on filamentous cyanobacteria, Estuar. Coast. Shelf S., 83, 434-442, https://doi.org/10.1016/j.ecss.2009.04.031, 2009.

Nehring, D. and Matthäus, W.: Current Trends in Hydrographic and Chemical Parameters and Eutrophication in the Baltic Sea, Int. Rev. Hydrobiol., 76, 297-316, https://doi.org/10.1002/iroh.19910760303, 1991.

Neumann, T.: Climate-change effects on the Baltic Sea ecosystem: A model study, J. Marine Syst., 81, 213-224, https://doi.org/10.1016/j.jmarsys.2009.12.001, 2010.

Neumann, T. and Schernewski, G.: An ecological model evaluation of two nutrient abatement strategies for the Baltic Sea, J. Marine Syst., 56, 195-206, https://doi.org/10.1016/j.jmarsys.2004.10.002, 2005.

Neumann, T. and Schernewski, G.: Eutrophication in the Baltic Sea and shifts in nitrogen fixation analysed with a 3D ecosystem model, J. Marine Syst., 74, 592-602, https://doi.org/10.1016/j.jmarsys.2008.05.003, 2008.

Neumann, T., Fennel, W., and Kremp, C.: Experimental simulations with an ecosystem model of the Baltic Sea: A nutrient load reduction experiment, Global Biogeochem. Cy., 16, https://doi.org/10.1029/2001gb001450, 2002.

Neumann, T., Eilola, K., Gustafsson, B., Müller-Karulis, B., Kuznetsov, I., Meier, H. E. M., and Savchuk, O. P.: Extremes of Temperature, Oxygen and Blooms in the Baltic Sea in a Changing Climate, AMBIO, 41, 574-585, https://doi.org/10.1007/s13280-012-0321-2, 2012.

Ning, S.-B., Guo, H.-L., Wang, L., and Song, Y.-C.: Salt stress induces programmed cell death in prokaryotic organism Anabaena, J. Appl. Microbiol., 93, 15-28, https://doi.org/10.1046/j.13652672.2002.01651.x, 2002.

Nordin, R. N. and Stein, J. R.: Taxonomic revision of Nodularia (Cyanophyceae/Cyanobacteria), Can. J. Botany, 58, 1211-1224, https://doi.org/10.1139/b80-151, 1980.

Nowicki, A., Dzierzbicka-Głowacka, L., Janecki, M., and Kałas, M.: Assimilation of the satellite SST data in the 3D CEMBS model, Oceanologia, 57, 17-24, https://doi.org/10.1016/j.oceano.2014.07.001, 2015.

Nowicki, A., Rak, D., Janecki, M., and Dzierzbicka-Głowacka, L.: Accuracy assessment of temperature and salinity computed by the 3D Coupled Ecosystem Model of the Baltic Sea (3D CEMBS) in the Southern Baltic, J. Oper. Oceanogr., 9, 67-73, https://doi.org/10.1080/1755876x.2016.1209368, 2016.

Nyholm, N.: Kinetics of phosphate limited algal growth, Biotechnol. Bioeng., 19, 467-492, https://doi.org/10.1002/bit.260190404, 1977.

O’Neil, J. M., Davis, T. W., Burford, M. A., and Gobler, C. J.: The rise of harmful cyanobacteria blooms: The potential roles of eutrophication and climate change, Harmful Algae, 14, 313-334, https://doi.org/10.1016/j.hal.2011.10.027, 2012. 
Oh, H.-M., Maeng, J., and Rhee, G.-Y.: Nitrogen and carbon fixation by Anabaena sp. isolated from a rice paddy and grown under P and light limitations, J. Appl. Phycol., 3, 335-343, https://doi.org/10.1007/BF00026096, 1991.

Ojaveer, H., Jaanus, A., Mackenzie, B. R., Martin, G., Olenin, S., Radziejewska, T., Telesh, I., Zettler, M. L., and Zaiko, A.: Status of biodiversity in the Baltic Sea, PloS One, 5, e12467, https://doi.org/10.1371/journal.pone.0012467, 2010.

Oliver, R. L.: Floating and Sinking in Gas-Vacuolate Cyanobacteria1, J. Phycol., 30, 161-173, https://doi.org/10.1111/j.00223646.1994.00161.x, 1994.

Olli, K., Kangro, K., and Kabel, M.: Akinete Production of Anabaena Lemmermannii and A. Cylindrica (Cyanophyceae) in Natural Populations of N- and P-Limited Coastal Mesocosms, J. Phycol., 41, 1094-1098, https://doi.org/10.1111/j.15298817.2005.00153.x, 2005.

Olofsson, M., Egardt, J., Singh, A., and Ploug, H.: Inorganic phosphorus enrichments in Baltic Sea water have large effects on growth, carbon fixation, and $\mathrm{N}_{2}$ fixation by Nodularia spumigena, Aquat. Microb. Ecol., 77, 111-123, https://doi.org/10.3354/ame01795, 2016.

Orchard, E. D., Ammerman, J. W., Lomas, M. W., and Dyhrman, S. T.: Dissolved inorganic and organic phosphorus uptake in Trichodesmium and the microbial community: The importance of phosphorus ester in the Sargasso Sea, Limnol. Oceanogr., 55, 1390-1399, https://doi.org/10.4319/lo.2010.55.3.1390, 2010.

Orcutt, K. M., Gundersen, K., and Ammerman, J. W.: Intense ectoenzyme activities associated with Trichodesmium colonies in the Sargasso Sea, Mar. Ecol. Prog. Ser., 478, 101-113, https://doi.org/10.3354/meps10153, 2013.

Paerl, H. W.: Nuisance Phytoplankton Blooms in Coastal, Estuarine and Inland Waters, Limnol. Oceanogr., 33, 823-847, https://doi.org/10.4319/lo.1988.33.4part2.0823, 1988.

Paerl, H. W.: Mitigating harmful cyanobacterial blooms in a human- and climatically-impacted world, Life, 4, 988-1012, https://doi.org/10.3390/life4040988, 2014.

Paerl, H. W. and Huisman, J.: Climate change: a catalyst for global expansion of harmful cyanobacterial blooms, Env. Microbiol. Rep., 1, 27-37, https://doi.org/10.1111/j.17582229.2008.00004.x, 2009.

Paerl, H. W. and Otten, T. G.: Harmful cyanobacterial blooms: causes, consequences, and controls, Microbial Ecol., 65, 9951010, https://doi.org/10.1007/s00248-012-0159-y, 2013.

Paerl, H. W. and Otten, T. G.: Duelling CyanoHABS: unravelling the environmental drivers controlling dominance and succession among diazotrophic and non- $\mathrm{N}_{2}$-fixing harmful cyanobacteria, Environ. Microbiol., 18, 316-424, https://doi.org/10.1111/14622920.13035, 2016.

Paerl, H. W., Valdes, L. M., Peierls, B. L., Adolf, J. E., Harding, J., and Lawrence, W.: Anthropogenic and climatic influences on the eutrophication of large estuarine ecosystems, Limnol. Oceanogr., 51, 448-462, https://doi.org/10.4319/1o.2006.51.1_part_2.0448, 2006.

Paerl, H. W., Hall, N. S., and Calandrino, E. S.: Controlling harmful cyanobacterial blooms in a world experiencing anthropogenic and climatic-induced change, Sci. Total Environ., 409, 17391745, https://doi.org/10.1016/j.scitotenv.2011.02.001, 2011.

Pechar, L.: Photosynthesis of Natural Populations of Aphanizomenon flos-aquae: Some Ecological Im- plications, Int. Rev. Ges. Hydrobio., 72, 599-606, https://doi.org/10.1002/iroh.19870720506, 1987.

Petersen, W., Colijn, F., Gorringe, P., Kaitala, S., Karlson, B., King, A., Lips, U., Ntoumas, M., Seppälä, J., Sørensen, K., Petihakis, G., de la Villéon, L. P., and Wehde, H.: Ferryboxes within Europe: state-of-the-art and integration in the european ocean observation system (EOOS), in: Operational oceanography serving sustainable marine development, EuroGOOS, Bergen, Norway, 63-70, 2018.

Ploug, H., Adam, B., Musat, N., Kalvelage, T., Lavik, G., Wolf-Gladrow, D., and Kuypers, M. M.: Carbon, nitrogen and $\mathrm{O}_{2}$ fluxes associated with the cyanobacterium Nodularia spumigena in the Baltic Sea, ISME J., 5, 1549-1558, https://doi.org/10.1038/ismej.2011.20, 2011.

Preuss, R. and von Toussaint, U.: Uncertainty quantification in ionsolid interaction simulations, Nucl. Instrum. Meth. B, 393, 2628, https://doi.org/10.1016/j.nimb.2016.10.033, 2017.

Prussin, A. J., Garcia, E. B., and Marr, L. C.: Total Concentrations of Virus and Bacteria in Indoor and Outdoor Air, Environ. Sci. Tech. Let., 2, 84-88, https://doi.org/10.1021/acs.estlett.5b00050, 2015.

Raateoja, M., Kuosa, H., and Hällfors, S.: Fate of excess phosphorus in the Baltic Sea: A real driving force for cyanobacterial blooms?, J. Sea Res., 65, 315-321, https://doi.org/10.1016/j.seares.2011.01.004, 2011.

Rakko, A. and Seppäälä, J.: Effect of salinity on the growth rate and nutrient stoichiometry of two Baltic Sea filamentous cyanobacterial species, Estonian Journal of Ecology, 63, 545570, https://doi.org/10.3176/eco.2014.2.01, 2014.

Redfield, A. C.: The biological control of chemical factors in the environment, Am. Sci., 46 pp., 230A-221, 1958.

Reinart, A. and Kutser, T.: Comparison of different satellite sensors in detecting cyanobacterial bloom events in the Baltic Sea, Remote Sens. Environ., 102, 74-85, https://doi.org/10.1016/j.rse.2006.02.013, 2006.

Reissmann, J. H., Burchard, H., Feistel, R., Hagen, E., Lass, H. U., Mohrholz, V., Nusch, G., Umlauf, L., and Wieczorek, G.: Vertical mixing in the Baltic Sea and consequences for eutrophication - A review, Prog. Oceanogr., 82, 47-80, https://doi.org/10.1016/j.pocean.2007.10.004, 2009.

Rengefors, K., Gustafsson, S., and Sthl-Delbanco, A.: Factors regulating the recruitment of cyanobacterial and eukaryotic phytoplankton from littoral and profundal sediments, Aquat. Microb. Ecol., 36, 213-226, https://doi.org/10.3354/ame036213, 2004.

Reynolds, C. S.: The Ecology of Phytoplankton, Ecology, Biodiversity and Conservation, Cambridge University Press, Cambridge, https://doi.org/10.1017/CB09780511542145, 2006.

Reynolds, C. S. and Walsby, A. E.: Water-blooms, Biol. Rev., 50, 437-481, https://doi.org/10.1111/j.1469-185X.1975.tb01060.x, 1975.

Reynolds, C. S. and Rodgers, M. W.: Cell- and colonydivision in Eudorina (Chlorophyta: Volvocales) and some ecological implications, Brit. Phycol. J., 18, 111-119, https://doi.org/10.1080/00071618300650151, 1983.

Rhee, G.-Y. and Lederman, T. C.: Effects of nitrogen sources on Plimited growth of Anabaena flosaquae, J. Phycol., 19, 179-185, https://doi.org/10.1111/j.0022-3646.1983.00179.x, 1983.

Riemann, L., Holmfeldt, K., and Titelman, J.: Importance of viral lysis and dissolved DNA for bacterioplankton activity in a P- 
limited estuary, Northern Baltic Sea, Microbial Ecol., 57, 286294, https://doi.org/10.1007/s00248-008-9429-0, 2009.

Rivkin, R. B. and Swift, E.: Phosphate uptake by the oceanic dinoflagellate Pyrocystis noctiluca, J. Phycol., 18, 113-120, https://doi.org/10.1111/j.1529-8817.1982.tb03164.x, 1982.

Robarts, R. D. and Zohary, T.: Temperature effects on photosynthetic capacity, respiration, and growth rates of bloomforming cyanobacteria, New Zeal. J. Mar. Fresh., 21, 391-399, https://doi.org/10.1080/00288330.1987.9516235, 1987.

Rohwer, F. and Youle, M.: Coral Reefs in the Microbial Seas, Plaid Press, 204 pp., ISBN 0982701209, 2010.

Roleda, M. Y., Mohlin, M., Pattanaik, B., and Wulff, A.: Photosynthetic response of Nodularia spumigenato UV and photosynthetically active radiation depends on nutrient ( $\mathrm{N}$ and P) availability, FEMS Microbiol. Ecol., 66, 230-242, https://doi.org/10.1111/j.1574-6941.2008.00572.x, 2008.

Rother, J. A. and Fay, P.: Sporulation and the development of planktonic blue-green algae in two Salopian meres, P. Roy. Soc. Lond. B Bio., 196, 317-332, https://doi.org/10.1098/rspb.1977.0043, 1977.

Rücker, J., Tingwey, E. I., Wiedner, C., Anu, C. M., and Nixdorf, B.: Impact of the inoculum size on the population of Nostocales cyanobacteria in a temperate lake, J. Plankton Res., 31, 11511159, https://doi.org/10.1093/plankt/fbp067, 2009.

Saraiva, S., Meier, H. E. M., Andersson, H., Höglund, A., Dieterich, C., Gröger, M., Hordoir, R., and Eilola, K.: Uncertainties in Projections of the Baltic Sea Ecosystem Driven by an Ensemble of Global Climate Models, Front. Earth Sci., 6, 1-18, https://doi.org/10.3389/feart.2018.00244, 2019.

Sarnelle, O.: Initial conditions mediate the interaction between Daphnia and bloom-forming cyanobacteria, Limnol. Oceanogr., 52, 2120-2127, https://doi.org/10.4319/lo.2007.52.5.2120, 2007.

Savchuk, O. P.: Nutrient biogeochemical cycles in the Gulf of Riga: scaling up field studies with a mathematical model, J. Marine Syst., 32, 253-280, https://doi.org/10.1016/S09247963(02)00039-8, 2002.

Savchuk, O. P.: Large-Scale Nutrient Dynamics in the Baltic Sea, 1970-2016, Front. Mar. Sci., 5, 1-20, https://doi.org/10.3389/fmars.2018.00095, 2018.

Savchuk, O. P., Gustafsson, B. G., and Müller-Karulis, B. BALTSEM: A marine model for decision support within the Baltic Sea Region, Baltic Nest Institute Technical Report, 7, 1-55, 2012.

Schartau, M., Wallhead, P., Hemmings, J., Löptien, U., Kriest, I., Krishna, S., Ward, B. A., Slawig, T., and Oschlies, A.: Reviews and syntheses: parameter identification in marine planktonic ecosystem modelling, Biogeosciences, 14, 1647-1701, https://doi.org/10.5194/bg-14-1647-2017, 2017.

Schernewski, G. and Neumann, T.: The trophic state of the Baltic Sea a century ago: a model simulation study, J. Marine Syst., 53, 109-124, https://doi.org/10.1016/j.jmarsys.2004.03.007, 2005.

Schoffelen, N. J., Mohr, W., Ferdelman, T. G., Littmann, S., Duerschlag, J., Zubkov, M. V., Ploug, H., and Kuypers, M. M. M.: Single-cell imaging of phosphorus uptake shows that key harmful algae rely on different phosphorus sources for growth, Sci. Rep.-UK, 8, 17182, https://doi.org/10.1038/s41598-018-35310w, 2018.

Schrum, C. and Backhaus, J. O.: Sensitivity of atmosphere - ocean heat exchange and heat content in the North Sea and the Baltic
Sea, Tellus A, 51, 526-549, https://doi.org/10.1034/j.16000870.1992.00006.x, 1999.

Sellner, K. G.: Physiology, ecology, and toxic properties of marine cyanobacteria blooms, Limnol. Oceanogr., 42, 1089-1104, https://doi.org/10.4319/lo.1997.42.5_part_2.1089, 1997.

Sellner, K. G. and Olli, K.: Copepod interactions with toxic and non-toxic cyanobacteria from the Gulf of Finland, Phycologia, 35, 177-182, https://doi.org/10.2216/i0031-8884-35-6S-177.1, 1996.

Sellner, K. G., Olson, M. M., and Kononen, K.: Copepod grazing in a summer cyanobacteria bloom in the Gulf of Finland, Hydrobiologia, 292-293, 249-254, https://doi.org/10.1007/978-94-0171347-4_33, 1994.

Shimoda, Y. and Arhonditsis, G. B.: Phytoplankton functional type modeling: Running before we can walk? A critical evaluation of the current state of knowledge, Ecol. Model., 320, 29-43, https://doi.org/10.1016/j.ecolmodel.2015.08.029, 2015.

Short, F. T. and Wyllie-Echeverria, S.: Natural and humaninduced disturbances of seagrasses, Environ. Conserv., 23, 1727, https://doi.org/10.1017/S0376892900038212, 1996.

Sigee, D. C., Selwyn, A., Gallois, P., and Dean, A. P.: Patterns of cell death in freshwater colonial cyanobacteria during the late summer bloom, Phycologia, 46, 284-292, https://doi.org/10.2216/06-69.1, 2007.

Silveira, C. B. and Rohwer, F. L.: Piggyback-the-Winner in hostassociated microbial communities, NPJ Biofilms Microbiomes, 2, 16010, https://doi.org/10.1038/npjbiofilms.2016.10, 2016.

Simis, S. G. H., Tijdens, M., Hoogveld, H. L., and Gons, H. J.: Optical changes associated with cyanobacterial bloom termination by viral lysis, J. Plankton Res., 27, 937-949, https://doi.org/10.1093/plankt/fbi068, 2005.

Sipiä, V. O., Kankaanpäa, H., T., Flinkman, J., Lahti, K., and Meriluoto, J. A. O.: Time-Dependent Accumulation of Cyanobacterial Hepatotoxins in Flunders (Platichthys flesus) and Mussels (Mytilus edulis) from the Northern Baltic Sea, Environ. Toxicol., 16, 330-336, https://doi.org/10.1002/tox.1040, 2001.

Śliwińska-Wilczewska, S., Cieszyńska, A., Konik, M., Maculewicz, J., and Latala, A.: Environmental drivers of bloom-forming cyanobacteria in the Baltic Sea: Effects of salinity, temperature, and irradiance, Estuar. Coast. Shelf S., 219, 139-150, https://doi.org/10.1016/j.ecss.2019.01.016, 2019.

Smirnov, N. N.: Chapter 4 - Nutrition, in: Physiology of the Cladocera, 2 edn., Academic Press, 39-88, https://doi.org/10.1016/B978-0-12-805194-8.00004-0, 2017.

Snoeijs-Leijonmalm, P., Schubert, H., and Radziejewska, T.: Biological Oceanography of the Baltic Sea, Springer, Dordrecht, Netherlands, 714 pp., ISBN-109402413170, 2017.

Sobol, I. M.: Global sensitivity indices for nonlinear mathematical models and their Monte Carlo estimates, Math. Comput. Simulat., 55, 271-280, https://doi.org/10.1016/S03784754(00)00270-6, 2001.

Sohm, J. A. and Capone, D. G.: Phosphorus dynamics of the tropical and subtropical north Atlantic: Trichodesmium spp. versus bulk plankton, Mar. Ecol. Prog. Ser., 317, 21-28, https://doi.org/10.3354/meps317021, 2006.

Sohm, J. A., Mahaffey, C., and Capone, D. G.: Assessment of relative phosphorus limitation of Trichodesmium spp. in the North Pacific, North Atlantic, and the north 
coast of Australia, Limnol. Oceanogr., 53, 2495-2502, https://doi.org/10.4319/lo.2008.53.6.2495, 2008.

Sohm, J. A., Webb, E. A., and Capone, D. G.: Emerging patterns of marine nitrogen fixation, Nat. Rev. Microbiol., 9, 499-508, https://doi.org/10.1038/nrmicro2594, 2011.

Solis, M., Pawlik-Skowrońska, B., Adamczuk, M., and Kalinowska, R.: Dynamics of small-sized Cladocera and their algal diet in lake with toxic cyanobacterial water blooms, Ann. Limnol.-Int. J. Lim., 54, 6, https://doi.org/10.1051/limn/2018001, 2018.

Sommer, F., Hansen, T., and Sommer, U.: Transfer of diazotrophic nitrogen to mesozooplankton in Kiel Fjord, Western Baltic Sea: a mesocosm study, Mar. Ecol. Prog. Ser., 324, 105-112, https://doi.org/10.3354/meps324105, 2006.

Sommer, U.: The role of $\mathrm{r}$ - and K-selection in the succession of phytoplankton in Lake Constance, Acta Oecol., 2, 327-342, https://doi.org/10.1007/BF00027228, 1981.

Sousa, W., Attayde, J. L., Rocha, E. D. S., and EskinaziSant'Anna, E. M.: The response of zooplankton assemblages to variations in the water quality of four man-made lakes in semi-arid north-eastern Brazil, J. Plankton Res., 30, 699-708, https://doi.org/10.1093/plankt/fbn032, 2008.

Stal, L. J., Albertano, P., Bergman, B., Bröckel, K. V., Gallon, J. R., Hayes, P. K., Sivonen, K., and Walsby, A. E.: BASIC: Baltic Sea cyanobacteria, an investigation of the structure and dynamics of water blooms of cyanobacteria in the Baltic Sea - responses to a changing environment, Cont. Shelf Res., 23, 1695-1714, https://doi.org/10.1016/j.csr.2003.06.001, 2003.

Stigebrandt, A., Rahm, L., Viktorsson, L., Ödalen, M., Hall, P. O. J., and Liljebladh, B.: A New Phosphorus Paradigm for the Baltic Proper, AMBIO, 43, 634-643, https://doi.org/10.1007/s13280013-0441-3, 2014.

Suikkanen, S., Kaartokallio, H., Hällfors, S., Huttunen, M., and Laamanen, M.: Life cycle strategies of bloom-forming, filamentous cyanobacteria in the Baltic Sea, Deep Sea Research Part II: Topical Studies in Oceanography, 57, 199-209, https://doi.org/10.1016/j.dsr2.2009.09.014, 2010.

Sulčius, S. and Holmfeldt, K.: Viruses of microorganisms in the Baltic Sea: current state of research and perspectives, Mar. Biol. Res., 12, 115-124, https://doi.org/10.1080/17451000.2015.1118514, 2016.

Sulčius, S., Simoliunas, E., Staniulis, J., Koreiviene, J., Baltrusis, P., Meskys, R., and Paskauskas, R.: Characterization of a lytic cyanophage that infects the bloom - forming cyanobacterium Aphanizomenon flos-aquae, FEMS Microbiol. Ecol., 91, 1-7, https://doi.org/10.1093/femsec/fiu012, 2015.

Sulčius, S., Slavuckytė, K., Januškaitė, M., and Pas̆kauskas, R.: Establishment of axenic cultures from cyanobacterium Aphanizomenon flos-aquae akinetes by micromanipulation and chemical treatment, Algal Res., 23, 43-50, https://doi.org/10.1016/j.algal.2017.01.006, 2017a.

Sulčius, S., Slavuckytè, K., and Paškauskas, R.: The predation paradox: Synergistic and antagonistic interactions between grazing by crustacean predator and infection by cyanophages promotes bloom formation in filamentous cyanobacteria, Limnol. Oceanogr., 62, 2189-2199, https://doi.org/10.1002/lno.10559, $2017 b$.

Suttle, C. A.: Viruses in the sea, Nature, 437, 356-361, https://doi.org/10.1038/nature04160, 2005.
Tang, E. P. Y., Tremblay, R., and Vincent, W. F.: Cyanobacterial dominance of polar freshwater ecosystems: are high-latitude mat-formers adapted to low temperature?, J. Phycol., 33, 171181, https://doi.org/10.1111/j.0022-3646.1997.00171.x, 1997.

Tang, H., Vanderploeg, H. A., Johengen, T. H., and Liebig, J. R.: Quagga musel (Dreissena rostriformis bugensis) selective feeding of phytoplankton in Saginaw Bay, J. Great Lakes Res., 40, 83-94, https://doi.org/10.1016/j.jglr.2013.11.011, 2014.

Taranu, Z. E., Zurawell, R. W., Pick, F., and Gregory-Eaves, I.: Predicting cyanobacterial dynamics in the face of global change: the importance of scale and environmental context, Global Change Biol., 18, 3477-3490, https://doi.org/10.1111/gcb.12015, 2012.

Thomas, R. H. and Walsby, A. E.: The Effect of Temperature on Recovery of Buoyancy by Microcystis, J. Gen. Microbiol., 132, 1665-1672, https://doi.org/10.1099/00221287-132-6-1665, 1986.

Tucker, S. and Pollard, P.: Identification of cyanophage Ma-LBP and infection of the cyanobacterium Microcystis aeruginosa from an Australian subtropical lake by the virus, Appl. Environ. Microb., 71, 629-635, https://doi.org/10.1128/AEM.71.2.629635.2005, 2005.

Unger, J., Endres, S., Wannicke, N., Engel, A., Voss, M., Nausch, G., and Nausch, M.: Response of Nodularia spumigena to $p \mathrm{CO}_{2}$ - Part 3: Turnover of phosphorus compounds, Biogeosciences, 10, 1483-1499, https://doi.org/10.5194/bg-10-1483-2013, 2013.

Urrutia-Cordero, P., Ekvall, M. K., and Hansson, L.-A.: Controlling Harmful Cyanobacteria: Taxa-Specific Responses of Cyanobacteria to Grazing by Large-Bodied Daphnia in a Biomanipulation Scenario, PloS One, 11, e0153032, https://doi.org/10.1371/journal.pone.0153032, 2016.

Üveges, V., Tapolczai, K., Krienitz, L., and Padisák, J.: Photosynthetic characteristics and physiological plasticity of an Aphanizomenon flos-aquae (Cyanobacteria, Nostocaceae) winter bloom in a deep oligo-mesotrophic lake (Lake Stechlin, Germany), Hydrobiologia, 698, 263-272, https://doi.org/10.1007/s10750-0121103-3, 2012.

Vahtera, E., Laanemets, J., Pavelson, J., Huttunen, M., and Kononen, K.: Effect of upwelling on the pelagic environment and bloom-forming cyanobacteria in the western Gulf of Finland, Baltic Sea, J. Marine Syst., 58, 67-82, https://doi.org/10.1016/j.jmarsys.2005.07.001, 2005.

Vahtera, E., Conley, D. J., Gustafsson, B. G., Kuosa, H., Pitkänen, H., Savchuk, O. P., Tamminen, T., Viitasalo, M., Voss, M., Wasmund, N., and Wulff, F.: Internal Ecosystem Feedbacks Enhance Nitrogen-fixing Cyanobacteria Blooms and Complicate Management in the Baltic Sea, AMBIO, 36, 186-194, https://doi.org/10.1579/00447447(2007)36[186:IEFENC]2.0.CO;2, 2007a.

Vahtera, E., Laamanen, M., and Rintala, J.-M.: Use of different phosphorus sources by the bloom-forming cyanobacteria Aphanizomenon flos-aquae and Nodularia spumigena, Aquat. Microb. Ecol., 46, 225-237, https://doi.org/10.3354/ame046225, $2007 \mathrm{~b}$.

Visser, P. M., Ibelings, B. W., and Mur, L. R.: Autumnal sedimentation of Microcystis spp. as result of an increase in carbohydrate ballast at reduced temperature, J. Plankton Res., 17, 919-933, https://doi.org/10.1093/plankt/17.5.919, 1995.

Visser, P. M., Verspagen, J. M. H., Sandrini, G., Stal, L. J., Matthijs, H. C. P., Davis, T. W., Paerl, H. W., and Huisman, J.: How rising $\mathrm{CO}_{2}$ and global warming may stimulate 
harmful cyanobacterial blooms, Harmful Algae, 54, 145-159, https://doi.org/10.1016/j.hal.2015.12.006, 2016.

Walsby, A. E. and Booker, M. J.: Changes in buoyancy of a planktonic blue-green alga in response to light intensity, Brit. Phycol. J., 15, 311-319, https://doi.org/10.1080/00071618000650321, 1980.

Walsby, A. E., Hayes, P. K., and Boje, R.: The gas vesicles, buoyancy and vertical distribution of cyanobacteria in the Baltic Sea, Eur. J. Phycol., 30, 87-94, https://doi.org/10.1080/09670269500650851, 1995.

Walsby, A. E., Hayes, P. K., Boje, R., and Stal, L. J.: The selective advantage of buoyancy provided by gas vesicles for planktonic cyanobacteria in the Baltic Sea, New Phytol., 136, 407417, https://doi.org/10.1046/j.1469-8137.1997.00754.x, 1997.

Walve, J. and Larsson, U.: Blooms of Baltic Sea Aphanizomenon sp. (Cyanobacteria) collapse after internal phosphorus depletion, Aquat. Microb. Ecol., 49, 57-69, https://doi.org/10.3354/ame01130, 2007.

Walve, J. and Larsson, U.: Seasonal changes in Baltic Sea seston stoichiometry: the influence of diazotrophic cyanobacteria, Mar. Ecol. Prog. Ser., 407, 13-25, https://doi.org/10.3354/meps08551, 2010.

Wang, Z.-H., Liang, Y., and Kang, W.: Utilization of dissolved organic phosphorus by different groups of phytoplankton taxa, Harmful Algae, 12, 113-118, https://doi.org/10.1016/j.hal.2011.09.005, 2011.

Ward, E. J. and Shumway, S. S.: Separating the grain from the chaff: particle selection in suspension- and depositfeeding bivalves, J. Exp. Mar. Biol. Ecol., 300, 83-130, https://doi.org/10.1016/j.jembe.2004.03.002, 2004.

Wasmund, N.: Occurrence of cyanobacterial blooms in the Baltic Sea in relation to environmental conditions, Int. Rev. Ges. Hydrobio., 82, 169-184, https://doi.org/10.1002/iroh.19970820205, 1997.

Wasmund, N.: Recruitment of bloom-forming cyanobacteria from winter/spring populations in the Baltic Sea verified by a mesocosm approach, Boreal Environ. Res., 22, 445-455, 2017.

Wasmund, N., Nausch, G., Schneider, B., Nagel, K., and Voss, M.: Comparison of nitrogen fixation rates determined with different methods: a study in the Baltic Proper, Mar. Ecol. Prog. Ser., 297, 23-31, https://doi.org/10.3354/meps297023, 2005.

Wasmund, N., Dutz, J., Kremp, A., and Zettler, M. L.: Biological Assessment of the Baltic Sea 2018, Meereswissenschaftliche Berichte, Warnemuende, 112, 1-100, https://doi.org/10.12754/msr-2019-0112, 2019.
Weinbauer, M. G. and Rassoulzadegan, F.: Are viruses driving microbial diversification and diversity?, Environ. Microbiol., 6, 111, https://doi.org/10.1046/j.1462-2920.2003.00539.x, 2003.

Weinbauer, M. G., Brettar, I., and Höfle, M. G.: Lysogeny and virus-induced mortality of bacterioplankton in surface, deep, and anoxic marine waters, Limnol. Oceanogr., 48, 1457-1465, https://doi.org/10.4319/lo.2003.48.4.1457, 2003.

Werner, M., Michalek, M., and Solvita, S.: Abundance and distribution of the Zebra mussel (Dreissena Polymorpha), available at: https://helcom.fi/wp-content/uploads/2020/06/ BSEFS-Abundance-and-distribution-of-the-Zebra-mussel.pdf (last access: 22 March 2021), 2012.

White, J. D. and Sarnelle, O.: Size-structured vulnerability of the colonial cyanobacterium, Microcystis aeruginosa,to grazing by zebra mussels (Dreissena Polymorpha), Freshwater Biol., 59, 514-525, https://doi.org/10.1111/fwb.12282, 2014.

Whitton, B. A., Grainger, S. L. J., Hawley, G. R. W., and Simon, J. W.: Cell-bound and extracellular phosphatase activities of cyanobacterial isolates, Microb. Ecol., 21, 85-98, https://doi.org/10.1007/bf02539146, 1991.

Whitton, B. A. and Potts, M.: The Ecology of Cyanobacteria, Their Diversity in Time and Space, Springer, Dordrecht, Netherlands, New York, Boston, London, Moskow, 1-669, ISBN100792347358, 2002.

Wommack, K. E., and Colwell, R. R.: Virioplankton: Viruses in aquatic Ecosystems, Mircobiology and Molecular Biology Review, 64, 69-114, https://doi.org/10.1128/MMBR.64.1.69114.2000, 2000.

Worden, A. Z., Follows, M. J., Giovannoni, S. J., Wilken, S., Zimmerman, A. E., and Keeling, P. J.: Environmental science. Rethinking the marine carbon cycle: factoring in the multifarious lifestyles of microbes, Science, 347, 1257594, https://doi.org/10.1126/science.1257594, 2015.

Yamamoto, T., Suzuki, M., Kim, K., and Asaoka, S.: Growth and uptake kinetics of phosphate by benthic microalga Nitzschia sp. isolated from Hiroshima Bay, Japan, Phycol. Res., 60, 223-228, https://doi.org/10.1111/j.1440-1835.2012.00653.x, 2012.

Yamamoto, Y., Kouchiwa, T., Hodoki, Y., Hotta, K., Uchida, H., and Harada, K.-I.: Distribution and identification of actinomycetes lysing cyanobacteria in a eutrophic lake, J. Appl. Phycol., 10, 391-397, https://doi.org/10.1023/A:1008077414808, 1998.

Zeigler Allen, L., McCrow, J. P., Ininbergs, K., Dupont, C. L., Badger, J. H., Hoffman, J. M., Ekman, M., Allen, A. E., Bergman, B., and Venter, J. C.: The Baltic Sea Virome: Diversity and Transcriptional Activity of DNA and RNA Viruses, mSystems, 2, e00125-16, https://doi.org/10.1128/mSystems.00125-16, 2017. 